\title{
Feasibility of gas-phase decontamination of gaseous diffusion equipment
}

Feb 1993

Oak Ridge Gaseous Dlffuslon Plant, TN (United States)

Reproduced and Distributed by:

U.S. DEPARTMENT OF ENERGY

Office of Scientific and Technical Information

P.O. Box 62

Oak Ridge, TN 37831

This document is

PUBLICLY RELEASABLE

B steeb

Authorizing Official

Date: 


\section{DISCLAIMER}

This report was prepared as an account of work sponsored by an agency of the United States Government. Neither the United States Government nor any agency Thereof, nor any of their employees, makes any warranty, express or implied, or assumes any legal liability or responsibility for the accuracy, completeness, or usefulness of any information, apparatus, product, or process disclosed, or represents that its use would not infringe privately owned rights. Reference herein to any specific commercial product, process, or service by trade name, trademark, manufacturer, or otherwise does not necessarily constitute or imply its endorsement, recommendation, or favoring by the United States Government or any agency thereof. The views and opinions of authors expressed herein do not necessarily state or reflect those of the United States Government or any agency thereof. 


\section{DISCLAIMER}

Portions of this document may be illegible in electronic image products. Images are produced from the best available original document. 


\section{$\mathrm{K} / \mathrm{TCD}--1048$

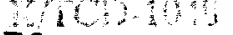 \\ DE93 009793}

FEASIBIIITY OF GAS-PHASE DECONTAMINATION

OF GASEOUS DIFFUSION EQUIPMENT

E. B. Munday

D. W. Simmons

Date Published-February 1993

Prepared by the

OAK RIDGE K-25 SITE

Oak Ridge, Tennessee 37831-7101

managed by

MARTIN MARIETTA ENERGY SYSTEMS, INC.

for the

U.S. DEPARTMENT OF ENERGY

under contract DE-AC05-84OR21400 


\section{CONTENTS}

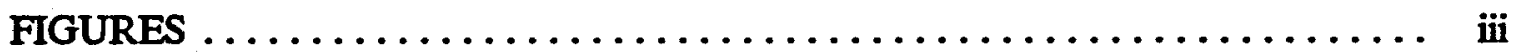

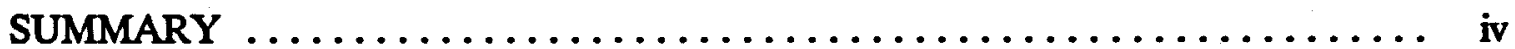

INTRODUCTION $\ldots \ldots \ldots \ldots \ldots \ldots \ldots \ldots \ldots \ldots \ldots \ldots \ldots \ldots \ldots \ldots \ldots$ vi

1. GAS-PHASE DECONTAMINATION CONCEPT $\ldots \ldots \ldots \ldots \ldots \ldots \ldots \ldots, 1$

1.1 FURNACE STAND METHOD $\ldots \ldots \ldots \ldots, \ldots, \ldots, \ldots, \ldots, 1$

1.2 CELL CIRCULATION METHOD $\ldots \ldots \ldots \ldots \ldots \ldots \ldots \ldots \ldots \ldots, 1$

1.3 LTLT METHOD $\ldots \ldots \ldots \ldots \ldots \ldots \ldots \ldots \ldots \ldots \ldots \ldots \ldots \ldots \ldots \ldots, 2$

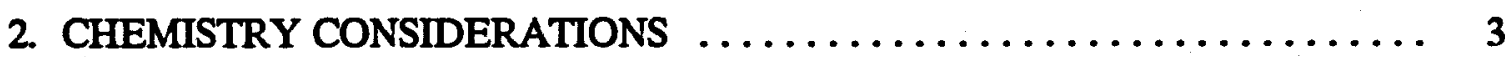

3. DESCRIPTION OF LABORATORY EQUIPMENT $\ldots \ldots \ldots \ldots \ldots \ldots \ldots, 5$

3.1 EXPERIMENTAL FLOW LOOP $\ldots \ldots \ldots \ldots \ldots \ldots \ldots \ldots \ldots \ldots, 5$

3.2 LTLT REACTORS $\ldots \ldots \ldots \ldots \ldots \ldots \ldots \ldots \ldots \ldots \ldots \ldots, 9$

4. EXPERIMENTAL OBJECTIVES AND BASIS

FOR SUCCESSFUL DECONTAMINATION $\ldots \ldots \ldots \ldots \ldots \ldots \ldots \ldots, \quad 12$

5. LABORATORY TEST RESULTS $\ldots \ldots \ldots \ldots \ldots \ldots \ldots \ldots \ldots \ldots, 13$

5.1 TEST SAMPLES $\ldots \ldots \ldots \ldots \ldots \ldots \ldots \ldots \ldots \ldots \ldots \ldots \ldots \ldots \ldots, 13$

5.2 EXPERIMENTAL FLOW LOOP RESULTS $\ldots \ldots \ldots \ldots \ldots \ldots \ldots, 13$

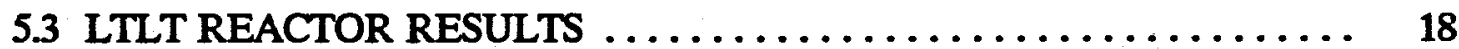

5.4 DECREASE IN RADIOACTIVE EMISSIONS FROM SAMPLES ..... 19

6. APPLICATION TO FULL_SCALE DECONTAMINATION $\ldots \ldots \ldots \ldots \ldots, 22$

6.1 FULL-SCALE DECONTAMINATION EQUIPMENT ............ 22

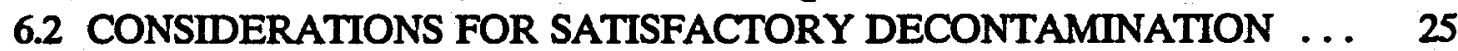

6.3 ADVANTAGES OF THE LTLT GAS-PHASE PROCESS .......... 26

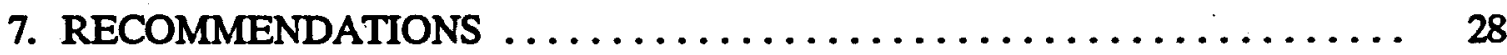

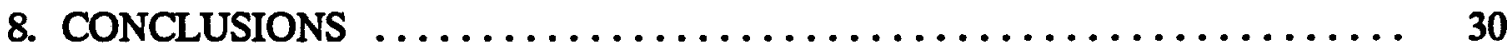

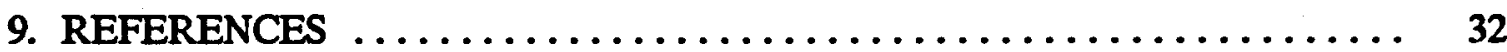

ACRONYMS, INITIALISMS, AND CHEMICAL FORMULAS .......... 34

Appendix A

ACCEPTABLE SURFACE DECONTAMINATION LEVELS $\ldots \ldots \ldots \ldots \ldots$ A-1

Appendix B

ADDITIONAL DATA AND PROCEDURAL DETAILS $\ldots \ldots \ldots \ldots \ldots \ldots$ B-1

Appendix C

PERTINENT RADIOACTIVE DECAY INFORMATION $\ldots \ldots \ldots \ldots \ldots \ldots$ C-1

Appendix D

COST COMPARISON AND ESTIMATES FOR DECONTAMINATION

USING THE LTLT PROCESS $\ldots \ldots \ldots \ldots \ldots \ldots \ldots \ldots \ldots \ldots \ldots \ldots . \ldots \ldots$ 


\section{FIGURES}

Figure

Page

1. Schematic of laboratory-scale flow loop equipment $\ldots \ldots \ldots \ldots \ldots \ldots \ldots$

2. View of flow loop equipment $\ldots \ldots \ldots \ldots \ldots \ldots \ldots \ldots \ldots \ldots \ldots \ldots$

3. Alternate view of flow loop equipment $\ldots \ldots \ldots \ldots \ldots \ldots \ldots \ldots \ldots \ldots$

4. Schematic of an LTLT laboratory reactor $\ldots \ldots \ldots \ldots \ldots \ldots \ldots \ldots \ldots \ldots$

5. View of the LTLT reactors $\ldots \ldots \ldots \ldots \ldots \ldots \ldots \ldots \ldots \ldots \ldots \ldots \ldots$

6. Pretreated sample with a heavy $\mathrm{UO}_{2} \mathrm{~F}_{2}$ deposit $\ldots \ldots \ldots \ldots \ldots \ldots \ldots$

7. Pretreated sample with a moderate $\mathrm{UO}_{2} \mathrm{~F}_{2}$ deposit $\ldots \ldots \ldots \ldots \ldots \ldots$

8. Percent deposit remaining vs time for the reaction of $\mathrm{CFF}_{3}$ at 4 psia,

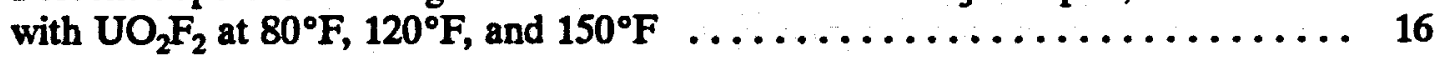

9. Sample treated with 4 psia of $\mathrm{ClF}_{3}$ at $75^{\circ} \mathrm{F}$ for $105 \mathrm{~d} \ldots \ldots \ldots \ldots \ldots \ldots$

10. Schematic of the full-scale LTLT equipment $\ldots \ldots \ldots \ldots \ldots \ldots \ldots \ldots \ldots$

11. Process steps for LTLT decontamination $\ldots \ldots \ldots \ldots \ldots \ldots \ldots \ldots \ldots \ldots$

12. Gas-phase demonstration schedule and cost $\ldots \ldots \ldots \ldots \ldots \ldots \ldots \ldots \ldots$

B-1. Temperature dependence for the reaction of $\mathrm{ClF}_{3}$ and $\mathrm{UO}_{2} \mathrm{~F}_{2}$ at

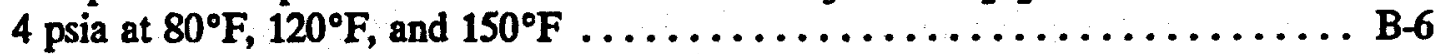

B-2. Ratio of the mol of $\mathrm{CF}_{3}$ consumed to the mol of $\mathrm{UF}_{6}$ recovered for the reaction of $\mathrm{CF}_{3}$ and $\mathrm{UO}_{2} \mathrm{~F}_{2}$ at 4 psia and $80^{\circ} \mathrm{F}, 120^{\circ} \mathrm{F}$, and $150^{\circ} \mathrm{F} \ldots . \mathrm{B}-7$ 


\section{SUMMARY}

The five buildings at the K-25 Site formerly involved in the gaseous diffusion process contain $\sim 5,000$ gaseous diffusion stages as well as support facilities that are internally contaminated with uranium deposits. The gaseous diffusion facilities located at the Portsmouth Gaseous Diffusion Plant (PORTS) and the Paducah Gaseous Diffusion Plant (PGDP) also contain similar equipment and will eventually close. The decontamination of these facilities will require the most cost-effective technology consistent with the criticality, health physics, industrial hygiene, and environmental concerns; the technology must be consistent with the desire to keep exposures to hazardous substances to levels as low as reasonably achievable (ALARA).

This report documents recent laboratory experiments that were conducted to determine the feasibility of gas-phase decontamination of the internal surfaces of the gaseous diffusion equipment that is contaminated with uranium deposits. In gas-phase decontamination a gaseous fluorinating agent is used to fluorinate the solid uranium deposits to gaseous uranium hexafluoride $\left(\mathrm{UF}_{6}\right)$, which can be recovered by chemical trapping or freezing. The laboratory results regarding the feasibility of the gas-phase process are encouraging. These results especially showed promise for a novel decontamination approach called the long-term, lowtemperature (LTLT) process. In the LTLT process, the procedures listed here are applied to equipment requiring decontamination.

1. The equipment is rendered leak tight.

2. It is evacuated, leak tested, and pretreated.

3. It is charged with chlorine trifluoride $\left(\mathrm{ClF}_{3}\right)$ to subatmospheric pressure.

4. It is left for an extended period, possibly $>4$ months, while processing other items.

5. The $\mathrm{UF}_{6}$ and other gases are evacuated. The $\mathrm{UF}_{6}$ is recovered by chemical trapping.

The lab results demonstrated that $\mathrm{ClF}_{3}$ gas at subatmospheric pressure and at $\sim 75^{\circ} \mathrm{F}$ is capable of volatilizing heavy deposits $\left(-1.3 \mathrm{~g} \mathrm{U} / \mathrm{in} .{ }^{2}\right)$ of uranyl fluoride $\left(\mathrm{UO}_{2} \mathrm{~F}_{2}\right)$ from copper metal surfaces sufficiently that the remaining radioactive emissions are below limits for unrestricted use as specified in Regulatory Guide 1.86. The samples were cut from a seal exhaust line from a K-33 building cascade. The uranium was removed by the process to the point that alpha emissions, which are characteristic radioactive emissions of uranium, were below the lower detection level of a Ludlum alpha meter $\left(80 \mathrm{dpm} / 100 \mathrm{~cm}^{2}\right)$. These results were obtained after the samples had been exposed to noncirculating $\mathrm{ClF}_{3}$ gas at an initial pressure of 4 psia contained inside reactor vessels for $\sim 105 \mathrm{~d}$ or fewer. The decontamination rate was observed to increase with increasing temperature $>75^{\circ} \mathrm{F}$, but the rate has an unusual temperature dependency. The rate was considerably higher at $120^{\circ} \mathrm{F}$ than at $75^{\circ} \mathrm{F}$, but was observed to be greater at $120^{\circ} \mathrm{F}$ than at $150^{\circ} \mathrm{F}$.

The LTLT approach is an in situ method with great payback potential since the items requiring decontamination act as the decontamination process vessels, thus greatly reducing the requirements for new decontamination equipment and facilities. The $\$ 348 \mathrm{M}$ cost estimated in the Ebasco study for pretreatment furnace stands would be eliminated by successful application of the LTLT process, and the \$174M cost for high-pressure water decontamination facilities would be considerably reduced. Operating cost may also be greatly reduced since the equipment can be treated in place and since conceivably entire cells could be treated at once in locations where the equipment is intact. Dismantlement costs are also 
expected to be greatly reduced since precautions necessary to prevent worker exposure to radiation and spread of contamination will be greatly simplified as a result of the in situ treatment. The process is expected to minimize criticality, safeguards, and ALARA concerns since it is an in situ, gas-phase process.

In some cascade locations, complete decontamination may prove difficult for these reasons:

- the presence of technetium $\left({ }^{99} \mathrm{Tc}\right)$ and neptunium $\left({ }^{237} \mathrm{~Np}\right)$,

- cracks or narrow passages where diffusion of gases may be slow,

- the presence of unusually nonreactive uranium deposits, and

- the presence of the ${ }^{231} \mathrm{~Pa}$ daughters of ${ }^{235} \mathrm{U}$ in high-enrichment areas if heavy deposits are present.

Even under the assumption that the process must be followed by a second decontamination step, the LTLT process would be very valuable. The Ebasco study assumed that a gas-phase treatment would be required as a pretreatment even though they also assumed that only $\sim 90 \%$ of the uranium would be recovered by the process; whereas, the lab process removed virtually all uranium.

Since the lab samples consisted of one type of uranium deposit $\left(\mathrm{UO}_{2} \mathrm{~F}_{2}\right)$ on one type of substrate (copper tube), the favorable results of this study cannot unconditionally be extrapolated to other types of uranium deposits and other types of substrates. Therefore, the lab studies should be continued to evaluate the effectiveness of the process on uranium contamination with different metal surfaces and to study the effects of different operating conditions on the reaction rates. Several important issues that could be determining factors concerning the practicality of the LTLT process cannot be entirely answered without a fullsize evaluation. The following aspects of the process must be examined:

- the process effectiveness on full-size equipment-because of the different uranium deposits that may be present, the different surface configurations, and the different metals present;

- practical methods for making the equipment requiring decontamination leak tight; and

- the manner in which the gases are to be processed at the end of the decontamination process.

Therefore, plans to design equipment for a full-size evaluation should proceed. These plans will include a thorough safety review. 


\section{INTRODUCTION}

The five buildings at the K-25 Site formerly used in the gaseous diffusion process contain $\sim 5,000$ gaseous diffusion stages as well as support facilities that are internally contaminated with uranium deposits. These areas also might have significant amounts of other radionuclides; principally technetium. Each stage consists of one or two compressors, a converter containing barrier, a gas cooler, and associated piping and valves. Both high-enrichment and lowenrichment facilities were operated at the K-25 Site. The uranium deposits are expected to be primarily in the form of $\mathrm{UO}_{2} \mathrm{~F}_{2}$ (perhaps $80 \%$ of the uranium deposits are in this form if the interior surfaces were exposed to air). The other uranium deposits would be principally in the form of uranium tetrafluoride $\left(\mathrm{UF}_{4}\right)$ mixed with $\mathrm{UO}_{2} \mathrm{~F}_{2}$ and other metal fluorides. After they are closed sometime in the next several decades, the PORTS and PGDP gaseous diffusion plants must also eventually be decontaminated. The removal of the internal uranium deposits will be a major portion of the overall decontamination effort. These activities will require the most effective technology available, and that technology must be consistent with the criticality, health physics, industrial hygiene, and environmental concerns; the technology also must be consistent with the desire to keep exposures to hazardous substances ALARA.

In gas-phase decontamination, a gaseous fluorinating agent (most likely $\mathrm{ClF}_{3}$ ) is used to fluorinate the solid uranium deposits to gaseous $\mathrm{UF}_{6}$, which can be recovered by chemical trapping. This approach offers unique advantages in meeting the previously mentioned concerns compared with other methods, since it provides an in situ process for removal of the deposits before the equipment is disassembled or moved from its location in the cascade. In addition to the considerable potential cost reduction compared with other methods, the process will most likely minimize criticality concerns better than any other process because the uranium is converted from a solid phase to a critically safe gas, which can be trapped into a chemical trap of critically safe geometry. Also, since the uranium is recovered as reusable $\mathrm{UF}_{6}$, radioactive wastes will be minimized.

This document reports laboratory results that support the feasibility of an in situ gas-phase decontamination process. This document also outlines preliminary concepts for fullscale application of the process to gaseous diffusion equipment, but since the project is in the early stages, many details and issues for full-scale implementation are beyond the scope of this report. 


\section{GAS-PHASE DECONTAMINATION CONCEPT}

In gas-phase decontamination, a gaseous reagent (usually $\mathrm{ClF}_{3}$ ) is employed to fluorinate nonvolatile uranium deposits to form volatile $\mathrm{UF}_{6}$, which can be recovered by chemical trapping or freezing. The uranium deposits are located on the interior surfaces of the gaseous diffusion equipment, such as converters, surge tanks, compressors, and piping. The decontamination process could conceptually be conducted in at least three ways that are further described in an article by Bundy and Munday. ${ }^{1}$ The three methods are as follows:

- furnace stand,

- cell circulation, and

- LTLT.

\subsection{FURNACE STAND METHOD}

Use of furnace stands in the decontamination process would require that the equipment be removed from the cascade and installed within the stand. The transportation and installation of the equipment into the stand would incur considerable expense in themselves, in addition to the cost of the furnace stands. Furnace stands are heated enclosures that can conceivably be operated at temperatures as high as $600^{\circ} \mathrm{F}$ but in practice were operated at considerably lower temperatures. As part of the installation process, the item requiring treatment is sealed into a process gas flow loop that passes through the furnace stand and allows the $\mathrm{ClF}_{3}$ gas to be circulated through the item being decontaminated while the item is heated. The process flow loop includes a compressor that forces the gases around the loop and auxiliary equipment and chemical traps for recovery of $\mathrm{UF}_{6}$ and handling of the off-gases. The furnace stand method was used at the U.S. gaseous diffusion plants (USGDPs) during the late 1940s and early 1950s for decontaminating converters to levels that would allow work to be done in the interior of the converters. Since these activities were intended to allow work on the equipment at the plant site, the investigators of the decontamination effectiveness usually reported only the resulting alpha wipe counts, which are indicative of transferable uranium. They sometimes reported alpha surface counts, but did not report beta or gamma emission levels. Therefore, a direct comparison of the effectiveness of current decontamination methods with the previously used methods is difficult.

\section{CELL CIRCULATION METHOD}

The concept of using the cascade compressors to circulate and heat the gas by compression was also used at the USGDPs in the early 1950s with the same objectives as the furnace stand process. The cell circulation method is being investigated for use at PORTS in a recently closed cascade. The considerable information available in the plant records on the previous activities has been assembled, but is not readily available except for the limited data published by Bundy and Munday. ${ }^{1}$ British Nuclear Fuels used the cell circulation method to pretreat their Capenhurst cascade with $\mathrm{ClF}_{3}$ before equipment was disassembled and further decontaminated. Details of the operating conditions, duration, and effectiveness of the 
process are not readily available. The cell method is no longer viable at the K-25 Site because the electrical lines to the compressors have already been removed.

\subsection{LTLT METHOD}

Fortunately, the lab results reported herein indicate that the cascade uranium deposits present in our lab samples, which represent many of the deposits found in the gaseous diffusion equipment, can be effectively removed within about 3 months or fewer at room temperature by a subatmospheric charge of noncirculating $\mathrm{ClF}_{3}$. The LTLT method seeks to compensate for the lower chemical reactivity at low temperature, noncirculating conditions by allowing the process to continue much longer than is practical with the furnace stand or cell methods previously used. Since the equipment that requires decontamination is no longer used in uranium enrichment production, the extended time (possibly $>4$ months) required of the process is no longer prohibitive. Since the LTLT method is a low-temperature method, a higher concentration of $\mathrm{ClF}_{3}$ gas can be used in the process equipment than could be safely used in a heated process that involves operating machinery with friction-producing moving parts. (Moving machine parts, especially compressors, increase the probability of accidents resulting from vigorous reaction of the $\mathrm{ClF}_{3}$ with bare metal surfaces that are heated to unusually high temperatures due to friction caused by machinery malfunction.) The increased concentration of $\mathrm{CFF}_{3}$ gas used in the LTLT method will largely offset the affect of the lower temperature used in the LTLT method. In addition, because the uranium deposits are exposed to $\mathrm{ClF}_{3}$ for such an extended time, the LTLT method is expected to be much more successful than the furnace stand method and the cell circulation method. 


\section{CHEMISTRY CONSIDERATIONS}

Potential candidates for this application include $\mathrm{ClF}_{3}$, fluorine $\left(\mathrm{F}_{2}\right)$, bromine trifluoride $\left(\mathrm{BrF}_{3}\right)$, iodine heptafluoride $\left(\mathrm{IF}_{7}\right)$, dioxygen difluoride $\left(\mathrm{O}_{2} \mathrm{~F}_{2}\right)$, and other strongly reactive fluorinating gases. The simplest of these gases to use from the viewpoint of the by-products generated during the reactions with the uranium deposits found in gaseous diffusion equipment is $\mathrm{F}_{2}$, but the reaction rate of this gas is much too slow at low temperatures. ${ }^{2} \mathrm{O}_{2} \mathrm{~F}_{2}$ is reportedly ${ }^{3}$ very reactive at room temperature, but it would probably disassociate before it could react with the deposits. $\mathrm{BrF}_{3}$ was evaluated at the $\mathrm{K}-25 \mathrm{Site}^{4-5}$ and was found to be more reactive than $\mathrm{ClF}_{3}$. However, its use was abandoned in favor of $\mathrm{ClF}_{3}$ because removing the low vapor pressure bromine by-products proved difficult, and the by-products were believed to pose greater explosion hazards than those associated with $\mathrm{ClF}_{3}$. IF 7 has been proposed by the Gesellschaft für Kernforschung M.B.H.; ${ }^{6}$ but the by-products of the $\mathrm{IF}_{7}$ reactions would be more difficult to handle than those resulting from $\mathrm{ClF}_{3}$ reactions because the iodine pentafluoride $\left(\mathrm{IF}_{5}\right)$ by-product is less volatile than $\mathrm{UF}_{6}$, which means it would freeze out with the $\mathrm{UF}_{6}$ if cold trapping were used to recover the $\mathrm{UF}_{6}$, and $\mathrm{IF}_{5}$ forms complexes with sodium fluoride (NaF), which means it would trap out with $\mathrm{UF}_{6}$ if an $\mathrm{NaF}$ trap were used for $\mathrm{UF}_{6}$ recovery. ${ }^{7}$ Freezing or trapping out the $\mathrm{IF}_{5}$ with the $\mathrm{UF}_{6}$ is undesirable since recovery of pure $\mathrm{UF}_{6}$ is desired and since the $\mathrm{IF}_{5}$ would decrease the trapping efficiency of the $\mathrm{NaF}_{\text {for }}$ the $\mathrm{UF}_{6}$. Also, $\mathrm{IF}_{7}$ is $\sim 15 \times$ more expensive than $\mathrm{ClF}_{3}$. These considerations have left $\mathrm{ClF}_{3}$ as the current gas of choice. The process equipment is primarily contaminated with $\mathrm{UO}_{2} \mathrm{~F}_{2}$, which results from the reaction of $\mathrm{UF}_{6}$ with moisture inleakage (perhaps $>80 \%$ of the uranium is in the form of $\mathrm{UO}_{2} \mathrm{~F}_{2}$ ), and $\mathrm{UF}_{4}$, which is a reduction product from the reaction of $\mathrm{UF}_{6}$ with the metal surfaces of the process equipment. If the system has been kept dry, other uranium fluorides and oxyfluorides are also possible. The reaction of $\mathrm{ClF}_{3}$ with $\mathrm{UO}_{2} \mathrm{~F}_{2}$ is complicated. Various investigators have studied the reaction, and the by-products they have reported have varied. Ellis and Forest ${ }^{8}$ give the following reaction formula:

$$
2 U O_{2} F_{2}+4 C l F_{3}-2 U F_{6}+C l_{2}+C l F+C l O_{2} F+O_{2}+F_{2}
$$

Shrewsberry and Williamson ${ }^{9}$ report a more complicated reaction involving a main reaction followed by secondary reactions as:

$$
\begin{array}{ll}
\mathrm{UO}_{2} \mathrm{~F}_{2}+2 \mathrm{ClF}_{3}-\mathrm{ClO}_{2} \mathrm{~F}+\mathrm{ClF}+\mathrm{UF}_{6} & \text { (main reaction) } \\
\mathrm{ClO} \mathrm{O}_{2}-\mathrm{ClF}+\mathrm{O}_{2} & \text { (partial secondary reaction) } \\
4 \mathrm{ClF}+\mathrm{UO}_{2} \mathrm{~F}_{2}-\mathrm{O}_{2}+2 \mathrm{Cl}_{2}+\mathrm{UF}_{6} & \text { (partial secondary reaction) }
\end{array}
$$


If the secondary reactions reach completion during high temperature and/or longer reaction times, the stoichiometry is represented by this net equation:

$$
4 \mathrm{ClF}_{3}+3 \mathrm{UO}_{2} \mathrm{~F}_{2}-3 \mathrm{O}_{2}+2 \mathrm{Cl}_{2}+3 \mathrm{UF}_{6}
$$

Other by-products such as chlorine dioxide $\left(\mathrm{ClO}_{2}\right)$ and chlorine trioxyfluoride $\left(\mathrm{ClO}_{3} \mathrm{~F}\right)$ have been reported, but these compounds probably result from the reaction of $\mathrm{ClF}_{3}$ with residual amounts of water rather than with $\mathrm{UO}_{2} \mathrm{~F}_{2}$. Although more complicated equations have been suggested, the reaction of $\mathrm{ClF}_{3}$ with $\mathrm{UF}_{4}$ can be written as ${ }^{10}$ :

$$
U F_{4}+\mathrm{ClF}_{3}-U F_{6}+C l F
$$

$\mathrm{ClF}_{3}$ is also expected to convert any other uranium compounds found in a cascade into $\mathrm{UF}_{6}$, but the reaction rate could vary considerably.

The $\mathrm{UF}_{6}$ generated by these reactions can be recovered by cold trapping or chemical trapping. More safety concerns would need to be addressed with cold trapping than with chemical trapping to avoid concentrating certain explosive chlorine oxides. ${ }^{11} \mathrm{NaF}$ pellets are an excellent trapping agent for removing $\mathrm{UF}_{6}$ from the gas stream since $\mathrm{UF}_{6}$ is trapped by this compound, but $\mathrm{ClF}_{3}$ and the by-product gases pass through unaffected. Also, the $\mathrm{UF}_{6}$ can later be recovered from the $\mathrm{NaF}$ pellets by heating the material to $\sim 600^{\circ} \mathrm{F}$ while purging the $\mathrm{NaF}$ pellets with $\mathrm{F}_{2}$ to prevent pellet deterioration. The $\mathrm{NaF}$ pellets can be reused many times by this procedure. The $\mathrm{ClF}_{3}$ and other toxic by-product gases can be trapped using a mixture of alumina and soda lime or removed by scrubber solutions such as potassium hydroxide solutions; but in a full-scale production process, a recycle method would need to be developed to allow recovery of excess $\mathrm{ClF}_{3}$ from the waste gases. 


\section{DESCRIPTION OF LABORATORY EQUIPMENT}

Two types of equipment were constructed for this laboratory-scale evaluation. They are described here.

- A flow loop that was originally intended to simulate furnace stand conditions was constructed. Fluorinating gases circulate through a small heated reactor. The loop is instrumented to allow monitoring of the reaction progress.

- Five simple test reactors were constructed. They were intended to contain small samples and a noncirculating charge of $\mathrm{CF}_{3}$ for evaluation of the LTLT concept.

After the evaluation was underway, the reaction of $\mathrm{ClF}_{3}$ with the uranium deposits was observed to proceed rapidly enough at room temperature $\left(-75^{\circ} \mathrm{F}\right)$ to abandon the furnace stand decontamination concept in favor of the LTLT concept.

\subsection{EXPERIMENTAL FLOW LOOP}

Figure 1 is a schematic of the experimental flow loop. The chief components proceeding around the loop clockwise are as follows:

1. the muffle furnace to allow heating of the reactor;

2. the reactor, which consists of a 1.9-in. ID nickel pipe $\sim 36$ in. long with a controlled heating zone of -6 in. (the reactor pipe passes through the furnace);

3. a corrosive gas manifold for charging $\mathrm{ClF}_{3}$ to the system;

4. a mass flow meter;

5. a Nicolet Model 510PC Fourier Transform Infrared Spectrometer (FTIR), which permits monitoring of the $\mathrm{ClF}_{3}$ consumption, $\mathrm{UF}_{6}$ generation, and most by-product gases;

6. the metal bellows pump for circulating the gases around the loop;

7. the pumping station for evacuating the gases through an alumina-soda lime trap (not shown) at the end of an experiment; and

8. a dry nitrogen manifold for administering dry nitrogen to the system as desired.

The loop also contains two thermocouples for temperature measurement and an electronic pressure indicator. The flow loop itself is made from $\% / 8$-in. nickel and copper tubing. The total system volume is $-4 \mathrm{~L}$. Figures 2 and 3 are photographs of different views of the flow loop equipment.

The flow loop, which is equipped with an FTIR, was used to monitor the rate of reaction between $\mathrm{ClF}_{3}$ and the uranium deposit samples at different conditions. Since the system volume is known, the amounts of $\mathrm{ClF}_{3}, \mathrm{UF}_{6}$, and certain other by-product gases can be estimated from the total system pressure and the partial pressures of the gas composition calculated from the FTIR spectra. The flow loop was pretreated with $F_{2}$ at $250^{\circ} \mathrm{F}$ to pacify the surfaces before the experiments. 


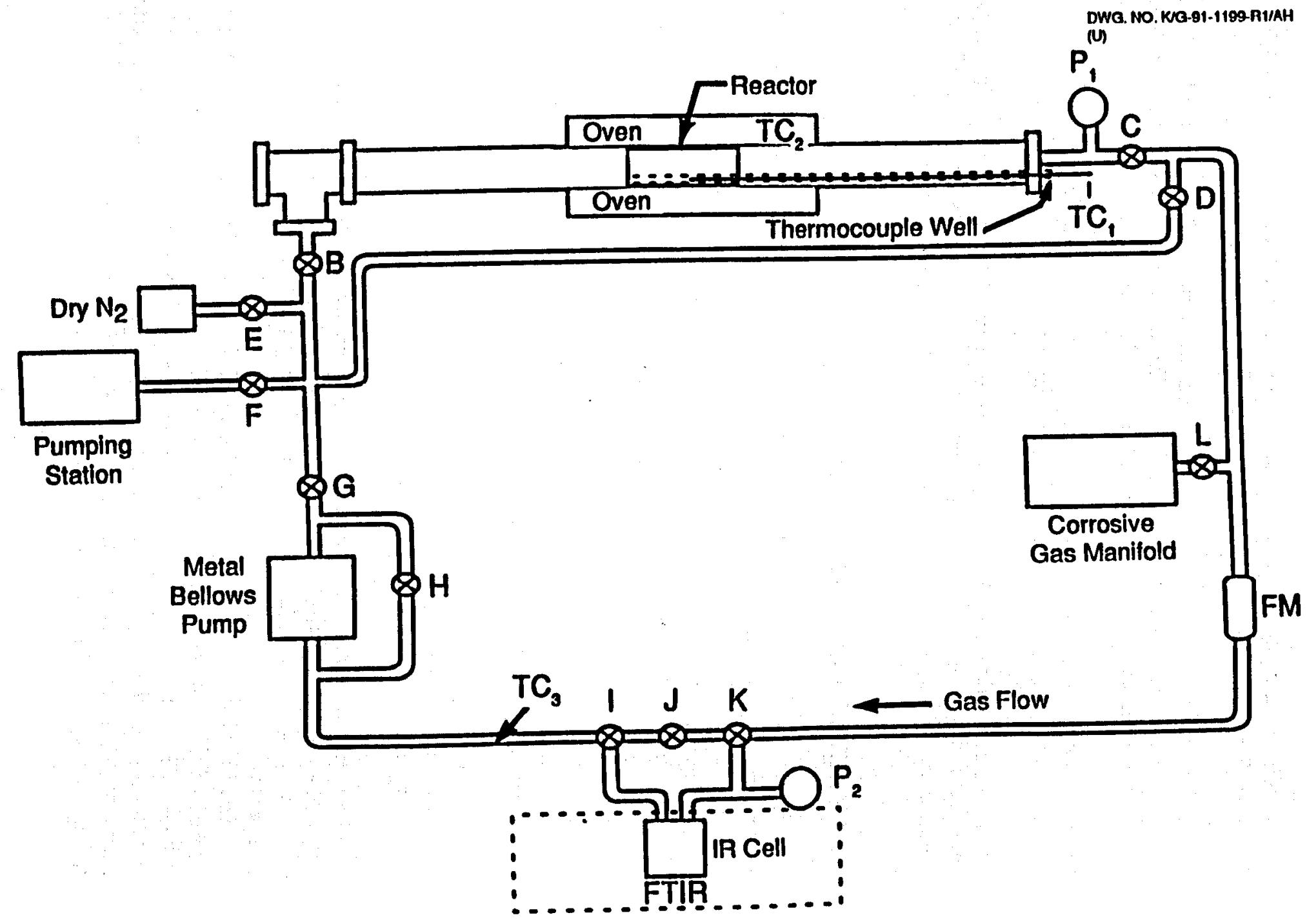

Fig. 1. Schematic of laboratory-scale flow loop equipment. 


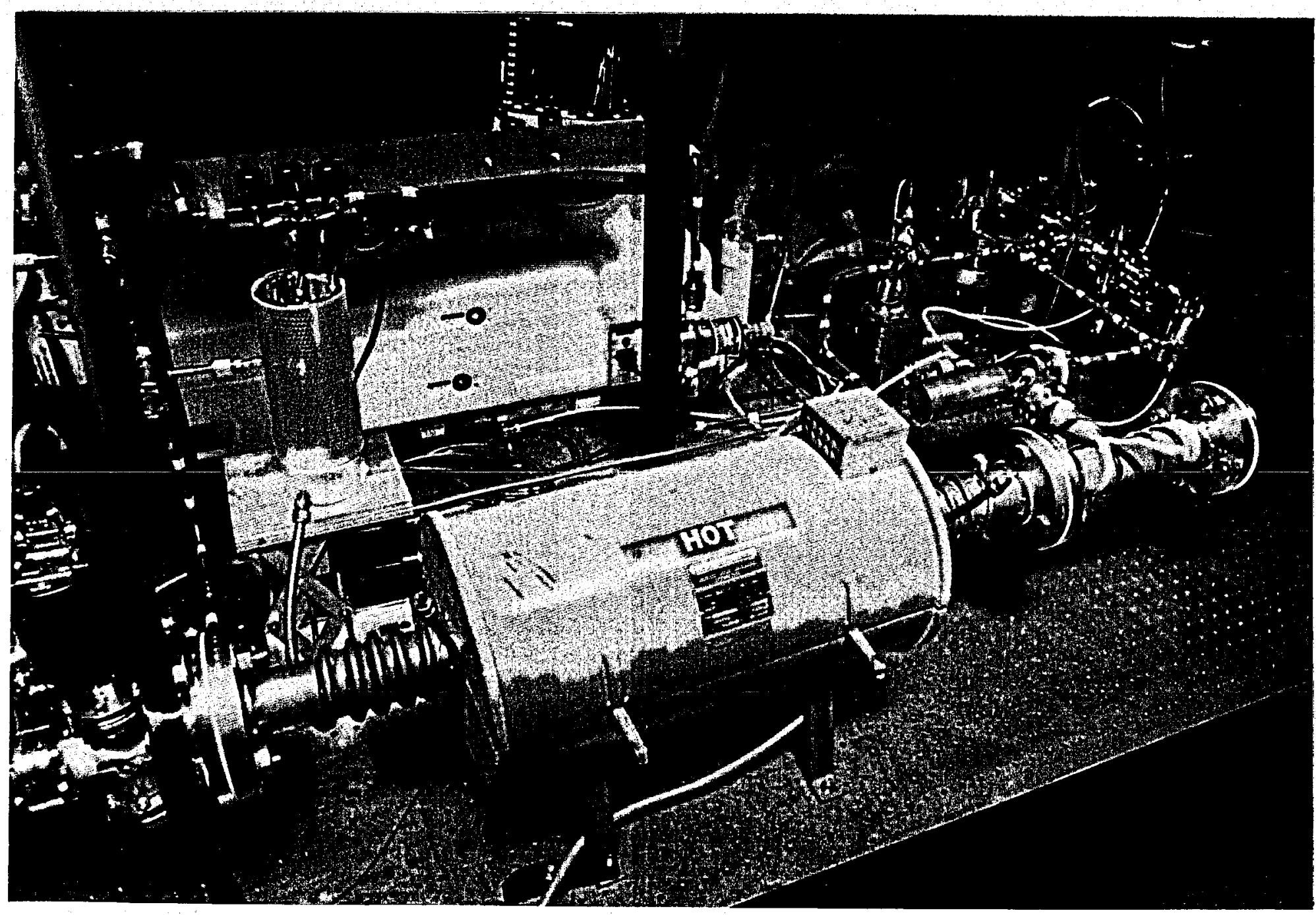

Fig. 2 View of flow loop equipment. 


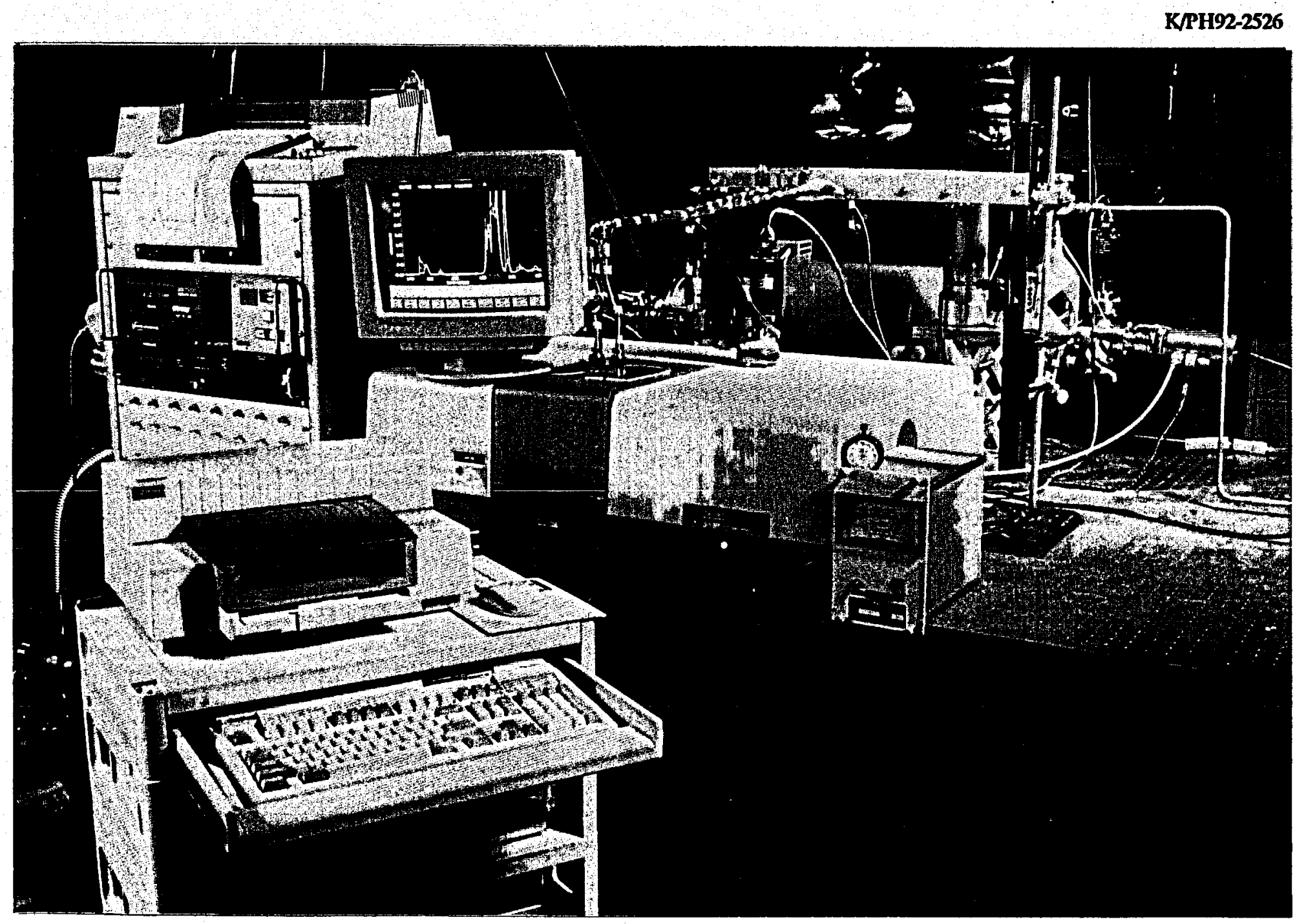

Fig. 3. Alternate view of flow loop equipment. 


\section{LTLT REACTORS}

Figure 4 is a schematic of the LTLT reactors. Five reactors were constructed specifically to evaluate the decontaminating effectiveness of a noncirculating charge of $\mathrm{ClF}_{3}$ at low temperature for an extended time. The reactors are 304 stainless steel tube sections, flanged on both ends. Each reactor has a bimetal thermometer that extends into a temperature well, a pressure gauge, a connection to a gas-handling manifold for charging and evacuating the reactor, and a connection to a safety exhaust manifold isolated from the reactor by a pressure relief valve. An FTIR was not available to allow monitoring of the reaction as in the test loop, but gas samples could be taken from the reactors via a connection on the gas manifold. All reactors were pretreated with $F_{2}$ gas at $150^{\circ} \mathrm{F}$ to pacify the surfaces before the experiments were begun. The 304 stainless steel served very well with $\mathrm{ClF}_{3}$ at the low temperature test conditions $\left(140^{\circ} \mathrm{F}\right.$ maximum). Initially, one reactor was used as a blank containing no uranium deposit sample. $\mathrm{ClF}_{3}$ was added to the reactor at a pressure of $4 \mathrm{psia}$, and the reactor was heated to $\sim 140^{\circ} \mathrm{F}$ for $\sim 28 \mathrm{~d}$. A pressure variance of $<0.5 \%$ was observed, which indicated no significant reaction between the $\mathrm{ClF}_{3}$ and the metal surfaces. Figure 5 is a photograph of the reactors. Three of the five reactors (the top reactors in Fig. 5) were wrapped with heat tape to allow for heated sample evaluation. Controllers regulated the temperature of the heated reactors within several degrees Fahrenheit. 
DWG. NO. KG-82-2512-R2DO

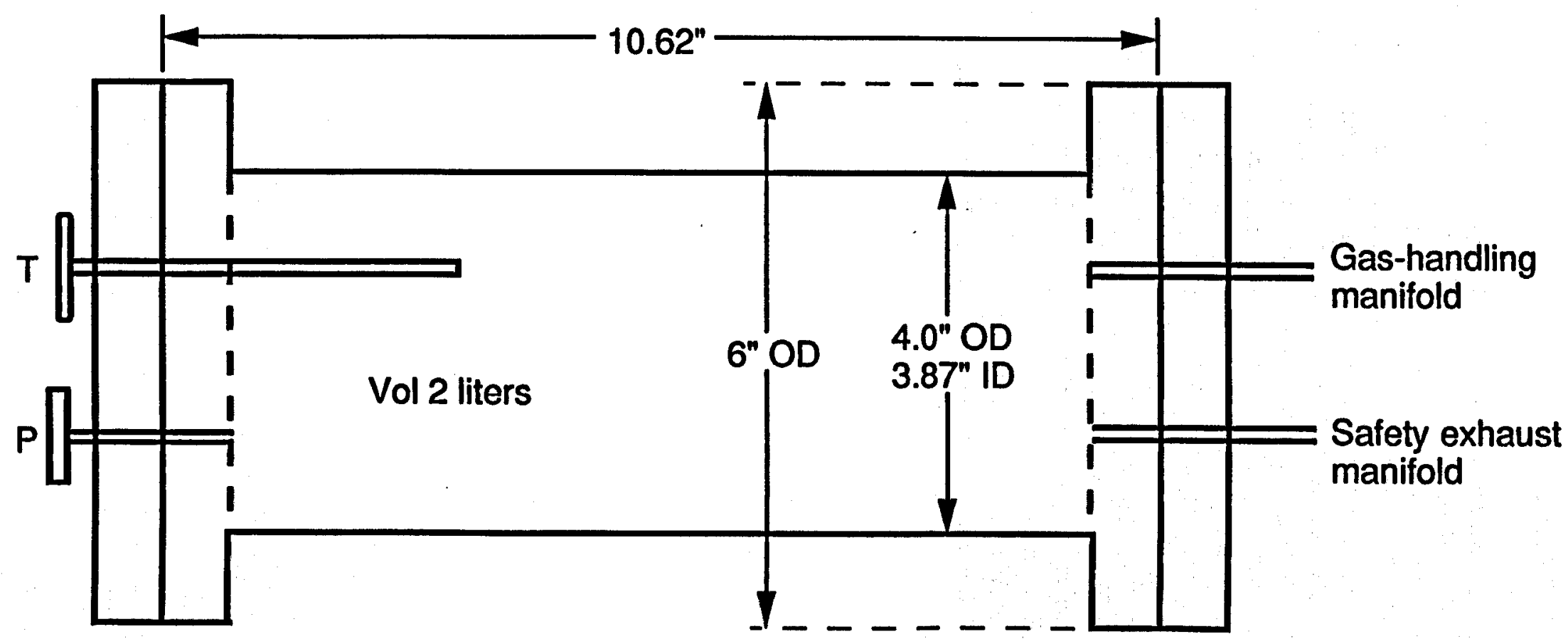

Fig. 4. Schematic of an LTLT laboratory reactor. 


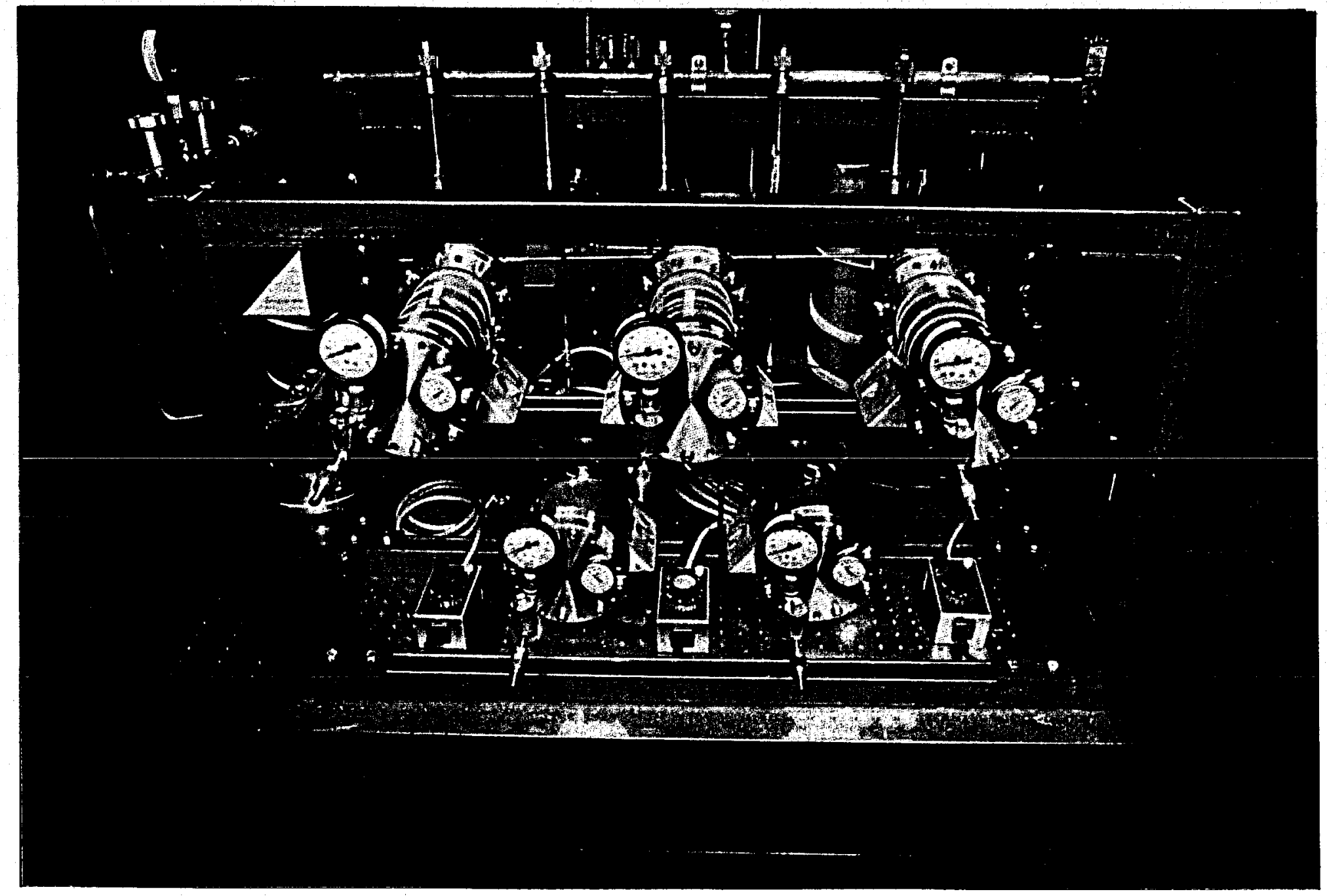




\section{EXPERIMENTAL OBJECTIVES AND BASIS FOR SUCCESSFUL DECONTAMMNATION}

To allow scaleup from lab-scale application, it is desirable to obtain reliable chemical reaction kinetics data and then use these with mass-transport calculations to predict process effectiveness in different applications. Obtaining reliable kineties data for the reactions of $\mathrm{CF}_{3}$ with uranium deposits found in cascade equipment has always presented numerous difficulties because the uranium deposits may be in the form of numerous uranium compounds or mixtures of the compounds. A given uranium compound can have different properties that will cause the reaction rate to vary, such as degree of hydration, surface area, crystal size, and density. Experimental evaluation of all the possibilities is not practical and simplifying assumptions are necessary. Since most of the deposits are believed to be in the form of $\mathrm{UO}_{2} \mathrm{~F}_{2}$ this compound is a logical choice for investigation.

A main objective in chemical reaction studies is to separate the effects of different variables such as temperature, pressure, and concentration. This objective requires that homogeneous samples be used; otherwise, the effects of changing process conditions cannot be distinguished from the sample variability. Numerous experimentalists have studied the reaction of $\mathrm{ClF}_{3}$ with uranium compounds at the USGDPs, but most of the data evaluated different conditions than reported in this study. One method that has been used to obtain homogeneous $\mathrm{UO}_{2} \mathrm{~F}_{2}$ samples for lab evaluations involves forming the samples on metal tubes inside the lab reactor by reacting $\mathrm{UF}_{6}$ with moist air. ${ }^{12}$ Unfortunately, the reactivity of the $\mathrm{UO}_{2} \mathrm{~F}_{2}$ formed by this procedure has been observed to decrease considerably with time, especially during the first several days of formation. ${ }^{12}$. This means that considerable experimental effort could be expended studying the reaction of $\mathrm{ClF}_{3}$ with newly formed $\mathrm{UO}_{2} \mathrm{~F}_{2}$ without the results being representative of the deposits in a cascade.

Considering this fact, the main thrust of these experiments was to obtain actual cascade samples and evaluate the effectiveness of $\mathrm{CF}_{3}$ in removing the uranium deposits without emphasis on reaction kinetics. Some useful kinetics information was obtained in the test loop, but the activity was not a principal objective. The reported lab results demonstrate the feasibility of the process on a lab scale, based upon the particular cascade samples. In this report, the basis for declaring successful decontamination is the achievement of acceptable decontamination levels for unrestricted use of surface-contaminated materials as specified in the U.S. Atomic Energy Commission (USAEC) Regulatory Guide $1.86^{13}$ (the now-nonexistent USAEC designation, issued in 1974, is still in force). This guide allows surface emissions of either alpha or beta radiation of $5,000 \mathrm{dpm} / 100 \mathrm{~cm}^{2}$ when averaged over a $\mathrm{m}^{2}$ surface. Maximum emissions must be $<15,000 \mathrm{dpm} / 100 \mathrm{~cm}^{2}$. Alpha and beta emission levels are applied independently of each other (Appendix $A$ contains full details). This guide applies only to surface contamination. Since the laboratory samples are small, the sample must not exceed $5,000 \mathrm{dpm} / 100 \mathrm{~cm}^{2}$ if it is to be considered successfully decontaminated. 


\section{LABORATORY TEST RESULTS}

\subsection{TEST SAMPLES}

Since the objective of this evaluation was to determine the feasibility of decontaminating gaseous diffusion equipment with $\mathrm{CF}_{3}$, the samples used in this evaluation were removed from actual cascade equipment. A length of $\%$-in. copper seal exhaust line with significant uranium deposits was identified by nondestructive analysis (NDA) gamma spectroscopy survey in the K-33 Process Building at the K-25 Site. About 120 in. of this line were removed from one location, and all samples evaluated in this study were cut from the line using a rotatingwheel tube cutter.

The uranium deposit was observed to be unusually heavy ( $\sim 2 \mathrm{~g}$ of elemental uranium per in. of tube on average). X-ray diffraction analysis indicated that the deposit is almost pure $\mathrm{UO}_{2} \mathrm{~F}_{2}$, and the sample had a uniform yellow color, typical of $\mathrm{UO}_{2} \mathrm{~F}_{2}$. The NDA gamma spectroscopy indicated that the uranium in the deposit is $\sim 0.65$ to $0.72 \%$ assay ${ }^{235} \mathrm{U}$. Samples of the deposit have been submitted for detailed chemical and radiological analysis, which resulted in a determination of $0.57 \%$ assay ${ }^{235} \mathrm{U}$. Also, virtually no ${ }^{99} \mathrm{Tc}$ or ${ }^{237} \mathrm{~Np}$ was present. Figures 6 and 7 are photographs of sections cut from the sample tube at different locations along the length. These photographs represent the visual variation in uranium deposit loading along the tube.

\subsection{EXPERIMENTAL FLOW LOOP RESULTS}

In all cases during the test loop evaluations, -1.5 in. of the $\%$-in. copper tube were placed in the reactor as samples. Each sample contained from $2.5 \mathrm{~g}$ to $3.7 \mathrm{~g}$ of elemental uranium.

Early in the experiments, $\mathrm{ClF}_{3}$ was observed to react with the uranium deposits at room temperature with unexpected speed. Subsequent experiments suggested that the reaction rate at low temperatures was sufficient to shift the investigation entirely to the LTLT concept as opposed to the high-temperature furnace stand concept. Since the flow loop has monitoring capabilities with the FTIR, it was used principally to evaluate reaction rates at various conditions for relatively short periods; whereas, the five LTLT reactors were used for longterm evaluations, as originally planned.

Figure 8 shows six plots of data taken with six samples in the experimental flow loop. One of the samples was evaluated at $80^{\circ} \mathrm{F}$, two at $150^{\circ} \mathrm{F}$, and three at $120^{\circ} \mathrm{F}$ with initial charges of 4 psia of $\mathrm{ClF}_{3}$ in each case. The percent of the deposit remaining is plotted on a log scale plot vs time. This figure indicates how the reaction slows as the deposit is consumed, and it indicates the effect of temperature. The reaction is seen to be a much weaker function of temperature than normally expected for chemical reactions. This means that heat does not increase the process effectiveness as much as previously believed, at least within the temperature range of our experiments. In fact, the plots of the reaction at $150^{\circ} \mathrm{F}$ is between the plots at $80^{\circ} \mathrm{F}$ and $120^{\circ} \mathrm{F}$, except for experiment 3-8, which is indistinguishable from the $150^{\circ} \mathrm{F}$ plots. (The reaction is faster at $120^{\circ} \mathrm{F}$ than at $75^{\circ} \mathrm{F}$, but is apparently faster at $120^{\circ} \mathrm{F}$ than at $150^{\circ} \mathrm{F}$.) From a practical viewpoint, these observations suggest that at the lower temperature range, the gas phase decontamination process may be aided more by slight heating rather than a greater amount of heating. Additional experimental data and procedural details are presented in Appendix B. 


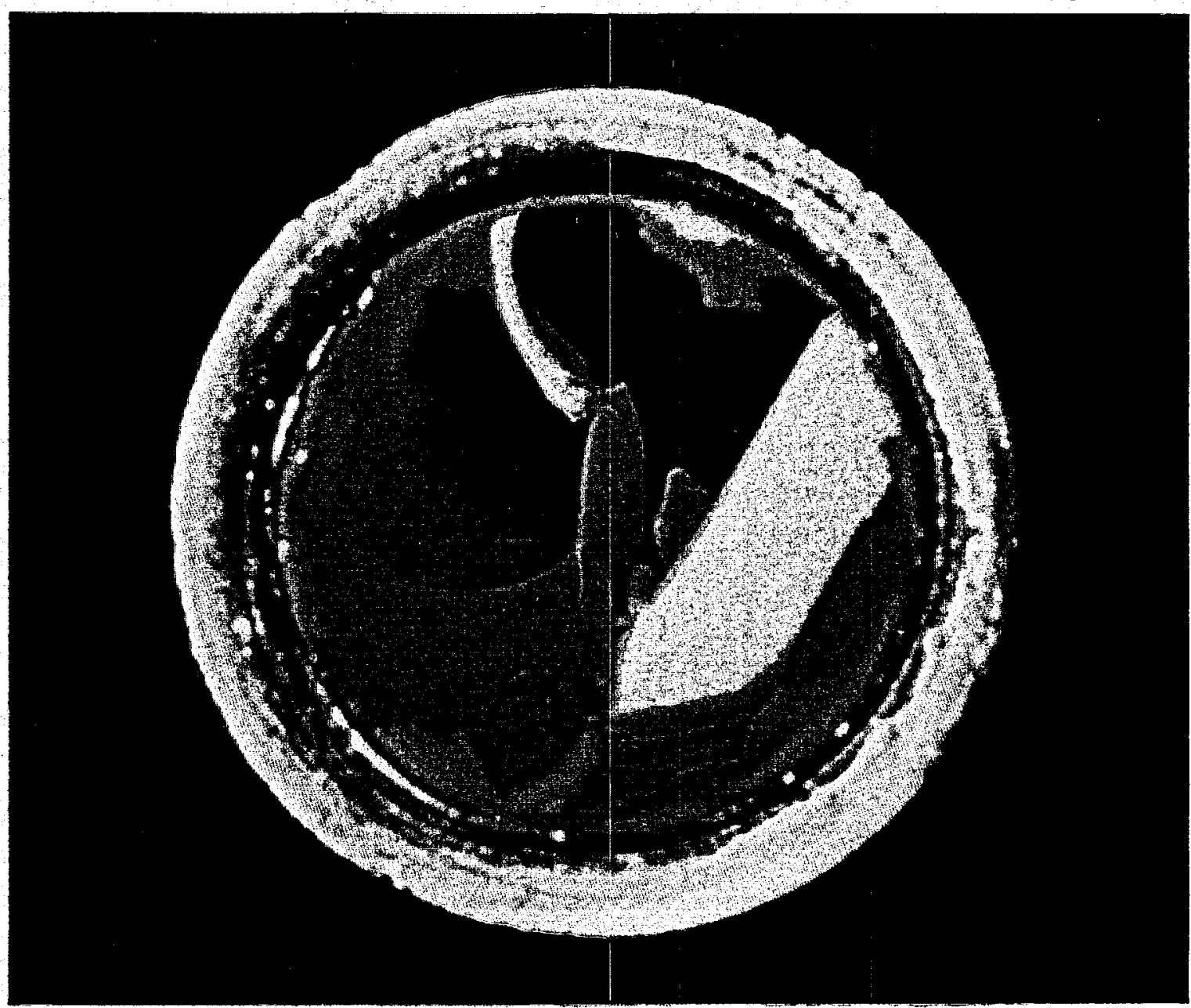

Fig. 6. Pretreated sample with a heavy $\mathrm{UO}_{2} \mathrm{~F}_{2}$ deposit.

The unusual temperature dependency is not unprecedented since changes in reaction mechanism with temperature are sometimes observed for complicated reactions. For example, kinetics studies for the $\mathrm{ClF}_{3}-\mathrm{UF}_{4}$ fluorination reaction conducted for the United Kingdom Atomic Energy Authority ${ }^{14}$ indicate that the reaction rate passes through a local maximum at $221^{\circ} \mathrm{F}$, falls to a local minimum of $298^{\circ} \mathrm{F}$, and then rises again. Other experimentalists ${ }^{12}$ observed a similar maximum value in reactivity with varying temperature for the $\mathrm{ClF}_{3}-\mathrm{UF}_{4}$ reaction, except the maximum temperature was reported at $235^{\circ}$ instead of $221^{\circ} \mathrm{F}$. Our results might indicate similar behavior for the $\mathrm{CIF}_{3}-\mathrm{UO}_{2} \mathrm{~F}_{2}$ reaction at a temperature range lower than that observed for the $\mathrm{ClF}_{3}-\mathrm{UF}_{4}$ reaction.

Table 1 displays a summary of experimental flow loop results that have been grouped according to the temperature being evaluated. Some of the sample numbers shown on Table 1 correspond to the sample numbers displayed in Fig. 8. The results show that $\sim 69 \%$ of the deposit was removed in only $2 \mathrm{~d}$ at $-80^{\circ} \mathrm{F}$. After $1 \mathrm{~d}$ of exposure at $150^{\circ} \mathrm{F}$, the deposit in sample 3-2 had been $83.9 \%$ volatilized. For the most part, the percent deposit removed at $120^{\circ} \mathrm{F}$ as reported in Table 1 confirms the previously observed result that the rate apparently exceeded that observed for the $150^{\circ} \mathrm{F}$ temperature. The results obtained with sample 3-8 are 


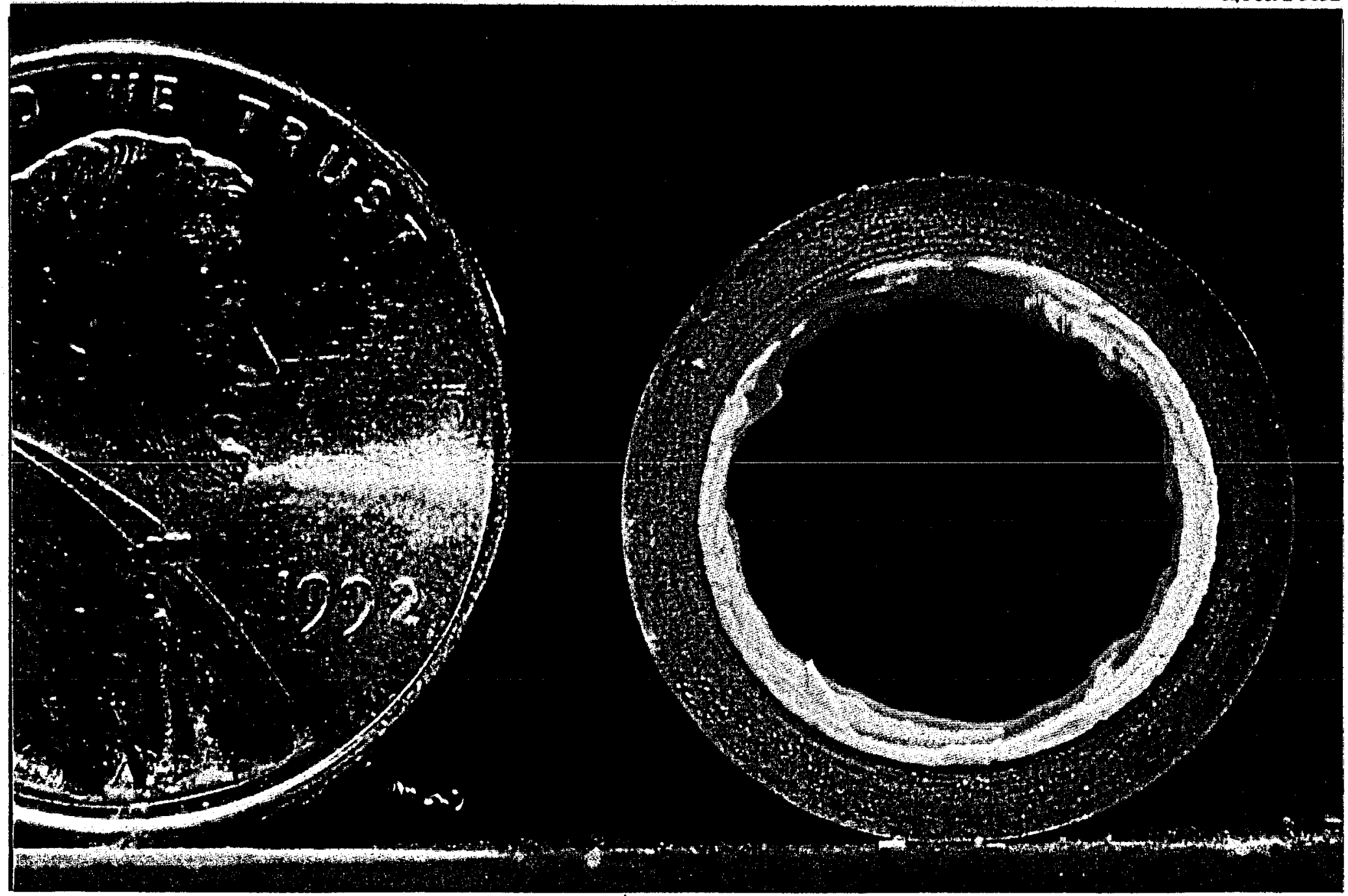

$\vec{u}$

Fig. 7. Pretreated sample with a moderate $\mathrm{UO}_{2} \mathrm{~F}_{2}$ deposit. 


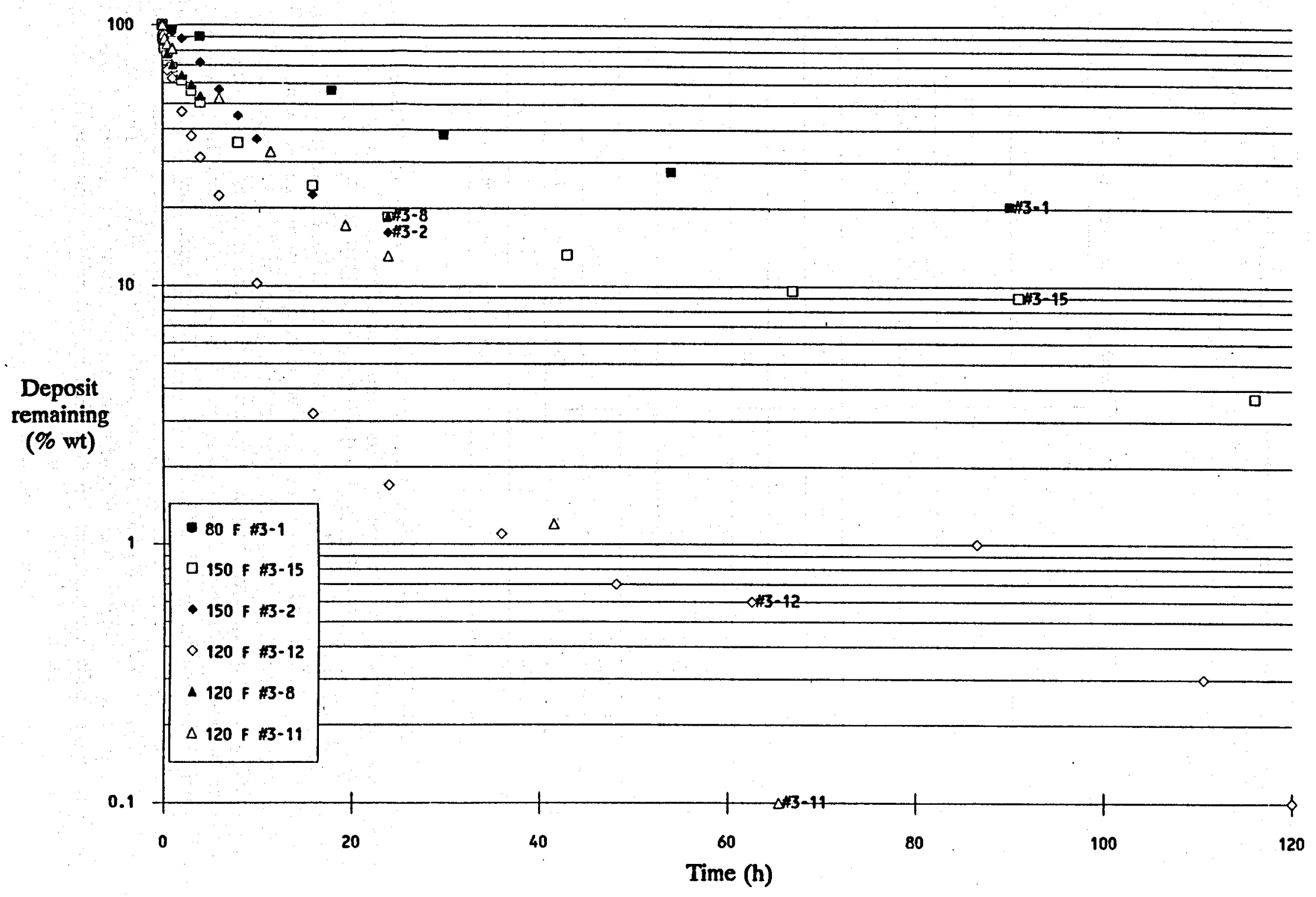

Fig. 8. Percent deposit remaining vs time for the reaction of $\mathrm{ClF}_{3}$ at 4 psia, with $\mathrm{UO}_{2} \mathrm{~F}_{2}$ at $80^{\circ} \mathrm{F}, 120^{\circ} \mathrm{F}$, and $150^{\circ} \mathrm{F}$. 
the exception to the observation as mentioned in comments concerning Fig. 8, considering that only $82.4 \%$ was converted after $1.8 \mathrm{~d}$ at $120^{\circ} \mathrm{F}$, compared with an $83.9 \%$ conversion at $150^{\circ} \mathrm{F}$ after $1 \mathrm{~d}$. Decreasing the pressure from 4 psia to 1 psia resulted in a dramatic decrease in reaction rate.

Table 1. Summary of experimental test loop results

\begin{tabular}{|c|c|c|c|c|c|}
\hline Sample & $\begin{array}{l}\text { Temp } \\
\left({ }^{\circ} \mathrm{F}\right)\end{array}$ & $\begin{array}{c}\mathrm{CF}_{3} \\
\text { pressure } \\
\text { (psia) }\end{array}$ & $\begin{array}{l}\text { Cumulative } \\
\text { exposure } \\
\text { (d) }\end{array}$ & $\begin{array}{c}\text { Deposit } \\
\text { removed } \\
\text { (\%) }\end{array}$ & Comments \\
\hline 3-1 & 80 & 4 & 8.3 & 90.5 & \\
\hline \multirow{3}{*}{ 3-3 } & 80 & 4 & 2 & 69 & Gases evacuated after 2 d. \\
\hline & 80 & 4 & 2.17 & 70.8 & Initially recharged with $\mathrm{ClF}_{\text {s. }}$ \\
\hline & 150 & 4 & 18.17 & 99.1 & $\begin{array}{l}\text { Initially temperature increased to } \\
150^{\circ} \mathrm{F} \text { to increase reaction ratc. }\end{array}$ \\
\hline $3-2$ & 150 & 4 & 1 & 83.9 & \\
\hline $3-15$ & 150 & 4 & 4.8 & 96.3 & \\
\hline 3-8 & 120 & 4 & 1.8 & 82.4 & \\
\hline \multirow{2}{*}{ 3-11 } & 120 & 4 & 4.8 & & Gases evacuated after $4.8 \mathrm{~d}$. \\
\hline & 120 & 4 & 5.8 & $>99.9$ & Initially new $\mathrm{CF}_{3}$ charge added. \\
\hline 3-12 & 120 & 4 & 5 & $>99.9$ & \\
\hline \multirow{2}{*}{ 3-13 } & 120 & 8 & 1 & 92.7 & Gases evacuated after 1 d. \\
\hline & 120 & 8 & 3.9 & 96.8 & Initially new $C F$, charge added. \\
\hline \multirow{2}{*}{ 3-14 } & 120 & 1 & 6 & & $\mathrm{ClF}_{3}$ consumed after $6 \mathrm{~d}$. \\
\hline & 120 & 1 & 7 & 52.8 & Initially new $\mathrm{CF}$, charge added. \\
\hline
\end{tabular}

Since the test loop was used mainly for short-term experiments, most of the uranium deposit on the samples was not reacted to completion. Sample 3-3 was one of the first samples evacuated. After initially reacting the sample at $\sim 80^{\circ} \mathrm{F}$, the gases were evacuated and a new charge of $\mathrm{ClF}_{3}$ was added to the reactor at the same pressure to see if the fresh charge of pure $\mathrm{ClF}_{3}$ would change the reaction rate, but no change was detected. The temperature was then increased from $80^{\circ} \mathrm{F}$ to $150^{\circ} \mathrm{F}$ and the sample was reacted for 16 additional days. Upon removal of the tube section from the reactor, a very light residue remained in the tube. The residue was easily wiped from the tube section. The tube was then split open and surveyed by a Health Physics Department technician for alpha and beta radioactive emissions using a Ludlum alpha meter and a Ludlum beta-gamma meter. The sample was found to have alpha and beta emissions $<5,000 \mathrm{dpm} / 100 \mathrm{~cm}^{2}$. This was the first tube section to be decontaminated; although not in a satisfactory manner since some of the residue was physically removed (Section 4 contains the decontamination criteria). Whenever a tube section was removed from a reactor before complete reaction, the residue was always observed to have loosened from the tube walls. X-ray diffraction of the residue indicated that it was also $\mathrm{UO}_{2} \mathrm{~F}_{2}$ 
The uranium deposits on samples 3-11 and 3-12 were completely reacted, resulting in alpha emissions that were less than the lower level of detection (LLD) of the alpha instrument $\left(\sim 80 \mathrm{dpm} / 100 \mathrm{~cm}^{2}\right)$. The beta emissions were only $\sim 1,000 \mathrm{dpm} / 100 \mathrm{~cm}^{2}$ and later decreased further. This result was obtained by gas action alone without wiping the tube section.

\subsection{LTLT REACTOR RESULTS}

In all cases during the LTLT reactor evaluations, $\sim 0.5$ in. of the $\%$-in. copper tube sample were placed in the reactor. Each sample contained $\sim 0.8$ to $1 \mathrm{~g}$ of elemented uranium. The sample size was restricted to ensure sufficient $\mathrm{CIF}_{3}$ for total reaction with the $\mathrm{UO}_{2} \mathrm{~F}_{2}$.

Since the purpose of the LTLT reactors was to evaluate the effectiveness of noncirculating charges of $\mathrm{CFF}_{3}$ at low temperatures for an extended time, the operation simply entailed placing a sample tube section in the reactor, evacuating the reactor, charging with $\mathrm{ClF}_{3}$, and waiting unit it was time to inspect the sample. Before evacuating the gases and opening the reactors, a gas sample was taken from the reactor for analysis on the FTIR. The gases were then evacuated, the reactor pressure increased to atmospheric pressure, and the samples removed. Several of the reactors were opened for inspection at intervals of a little more than $30 \mathrm{~d}$; whereas, others were left undisturbed until the inspection results from the reactors indicated that the reaction was probably complete.

The results obtained from the LTLT reactors are summarized in Table 2. More than 92\% of the deposit on sample 3-4 was removed by reaction after the first $34.8 \mathrm{~d}$ at $\sim 75^{\circ} \mathrm{F}$ with a 4 psia charge of $\mathrm{CIF}_{3}$. The sample was reinstalled in the reactor and recharged with $\mathrm{ClF}_{3}$, then removed again after another $38.3 \mathrm{~d}$ (73.1 cumulative d). The deposit removal rate was

Table 2 LTLT gas-phase decontamination results

\begin{tabular}{|c|c|c|c|c|c|}
\hline Sample & $\begin{array}{c}\text { Temp } \\
\left({ }^{\bullet}\right)\end{array}$ & $\underset{\text { (psia) }}{\mathrm{CF}_{3}}$ & $\begin{array}{c}\text { Exposure } \\
\text { (cumulative) }\end{array}$ & $\begin{array}{c}\text { Deposit } \\
\text { removed } \\
(\%)\end{array}$ & Comments \\
\hline $3-4^{\prime \prime}$ & 75 & 4 & $\begin{array}{r}34.8 \\
73.1 \\
105.2 \\
\end{array}$ & $\begin{array}{l}92.7 \\
99.3 \\
99.9 \\
\end{array}$ & $\begin{array}{l}\text { Removed two times for inspection } \\
\text { during the } 105.2-d \text { period }\end{array}$ \\
\hline $3-5^{2}$ & 140 & 4 & 34.8 & 99.9 & Undisturbed \\
\hline $3-6$ & 75 & 4 & 91.1 & 99.3 & $\begin{array}{l}\text { Leak developed in the reactor } \\
\text { pressure relief valve }\end{array}$ \\
\hline 3-7 & 140 & 4 & 93.7 & 99.9 & Undisturbed \\
\hline $3.9^{a}$ & 75 & 8 & $\begin{array}{l}36.7 \\
67.8\end{array}$ & $\begin{array}{l}99.6 \\
99.9\end{array}$ & $\begin{array}{l}\text { Removed once for inspection } \\
\text { during the } 67.8-d \text { period }\end{array}$ \\
\hline $3-10^{2}$ & 75 & 1 & $\boldsymbol{b}$ & $b$ & $b$ \\
\hline
\end{tabular}

Reactor contained an NaF trap during the evaluation.

SSample is still being processed. 
99.3\%. A final treatment lasting $32.1 \mathrm{~d}$ removed virtually all uranium, which is nominally shown as $99.9 \%$ removal. The percent removal was determined gravimetrically as explained in Appendix B. In cases in which a $99.9 \%$ removal is shown, the uranium was removed to a level in which alpha emissions were below the LLD of the Ludlum alpha meter $\left(\sim 80 \mathrm{dpm} / 100 \mathrm{~cm}^{2}\right)$, which is well below the decontamination criteria explained in Sect. 4. The results obtained with sample $3-5$ at $140^{\circ}$ reflect the faster reaction at that temperature. Increasing the pressure from 4 psia to 8 psia during the sample 3-9 evaluation apparently resulted in a significantly faster reaction (compare 3-9 and 3-4); whereas, decreasing the pressure to 1 psia is expected to decrease the rate (the evaluation with 3-10 is ongoing). In all cases the deposit removal was $>99.9 \%$, except for sample evaluation 3-6 in which a pressure relief valve leak developed that admitted nitrogen into the reactor. The temperature of the reactors fluctuated with the temperature of the lab during the low-temperature (nominally $75^{\circ} \mathrm{F}$ ) evaluations.

Figure 9 is a photograph of tube section, sample $3-4$, after decontamination at $75^{\circ} \mathrm{F}$ with $\mathrm{ClF}_{3}$ at 4 psia. As photographed, the sample is still in the reactor. The tube section interior still retained a small amount of very slightly radioactive (beta-emitting) residue. The beta emissions were most likely due to residual decay daughters of ${ }^{238} \mathrm{U}$. This residue was not removed before the radiation surveys, which indicated that both the alpha and beta emissions were below the decontamination levels. The object in the background is a copper cup that contains several hundred grams of $\mathrm{NaF}$ pellets. $\mathrm{NaF}$ was installed in the four reactors that contained the samples, indicated by footnote $a$ in Table 2. The NaF removes the $\mathrm{UF}_{6}$ as it is generated, which could improve the reaction kinetics; although the experiments to date have not clearly shown this. The NaF pellets did, however, help prevent the thorium daughter of ${ }^{238} \mathrm{U}$ from being deposited everywhere inside the reactors, as reported in the next section. Additional information and data are contained in Appendix B.

\subsection{DECREASE IN RADIOACTIVE EMISSIONS FROM SAMPLES}

A sample of ${ }^{238} \mathrm{U}$ that has remained in the solid phase for $>240 \mathrm{~d}$ will have established an equilibrium between the alpha decay of the ${ }^{238} \mathrm{U}$ and the beta decay of its two short halflived daughters, ${ }^{234} \mathrm{Th}$ and ${ }^{234} \mathrm{~Pa}$. The ${ }^{238} \mathrm{U}$ will also be in equilibrium with its more remote, long-lived daughter, ${ }^{234} \mathrm{U}$, because the ${ }^{238} \mathrm{U}$ is in equilibrium with ${ }^{234} \mathrm{U}$ in uranium ore. The ${ }^{234} \mathrm{U}$ is extracted from the ore along with the ${ }^{238} \mathrm{U}$ and ${ }^{235} \mathrm{U}$. When a radioactive parent is in equilibrium with its decay daughters, the activity (disintegrations per unit time) of each daughter equals that of the parent. Consequently, the number of disintegrations per unit time is the same for ${ }^{238} \mathrm{U},{ }^{234} \mathrm{U},{ }^{234} \mathrm{Th}$, and ${ }^{234} \mathrm{~Pa}$. ${ }^{15-16}$ The total activity of the sample will be four times the activity of pure ${ }^{238} \mathrm{U}$ with one-half of the activity being alpha and one-half being beta radiation. If the ${ }^{238} \mathrm{U}$ and ${ }^{234} \mathrm{U}$ are removed by reaction with $\mathrm{ClF}_{3}$, the ${ }^{234} \mathrm{Th}$ and ${ }^{234} \mathrm{~Pa}$ remain behind since they do not form volatile fluoride compounds. These nuclides decay relatively quickly because of their short half-lives; $24.1 \mathrm{~d}$ for ${ }^{234} \mathrm{Th}$, and $1.2 \mathrm{~min}$ for ${ }^{234} \mathrm{~Pa}$. The ${ }^{234} \mathrm{~Pa}$, which was formed by the decay of the ${ }^{234} \mathrm{Th}$, in turn decays to ${ }^{234} \mathrm{U}$, which will emit relatively very few counts because of the small amount generated and because of its relatively long half-life ( $2.48 \times 10^{5}$ years). Appendix $C$ contains additional pertinent radioactive decay information.

Table 3 contains a summary of alpha and beta survey readings for some of the decontaminated samples. The tube sections were split open and flattened after decontamination to allow improved surveying. This table shows that for most samples the beta 


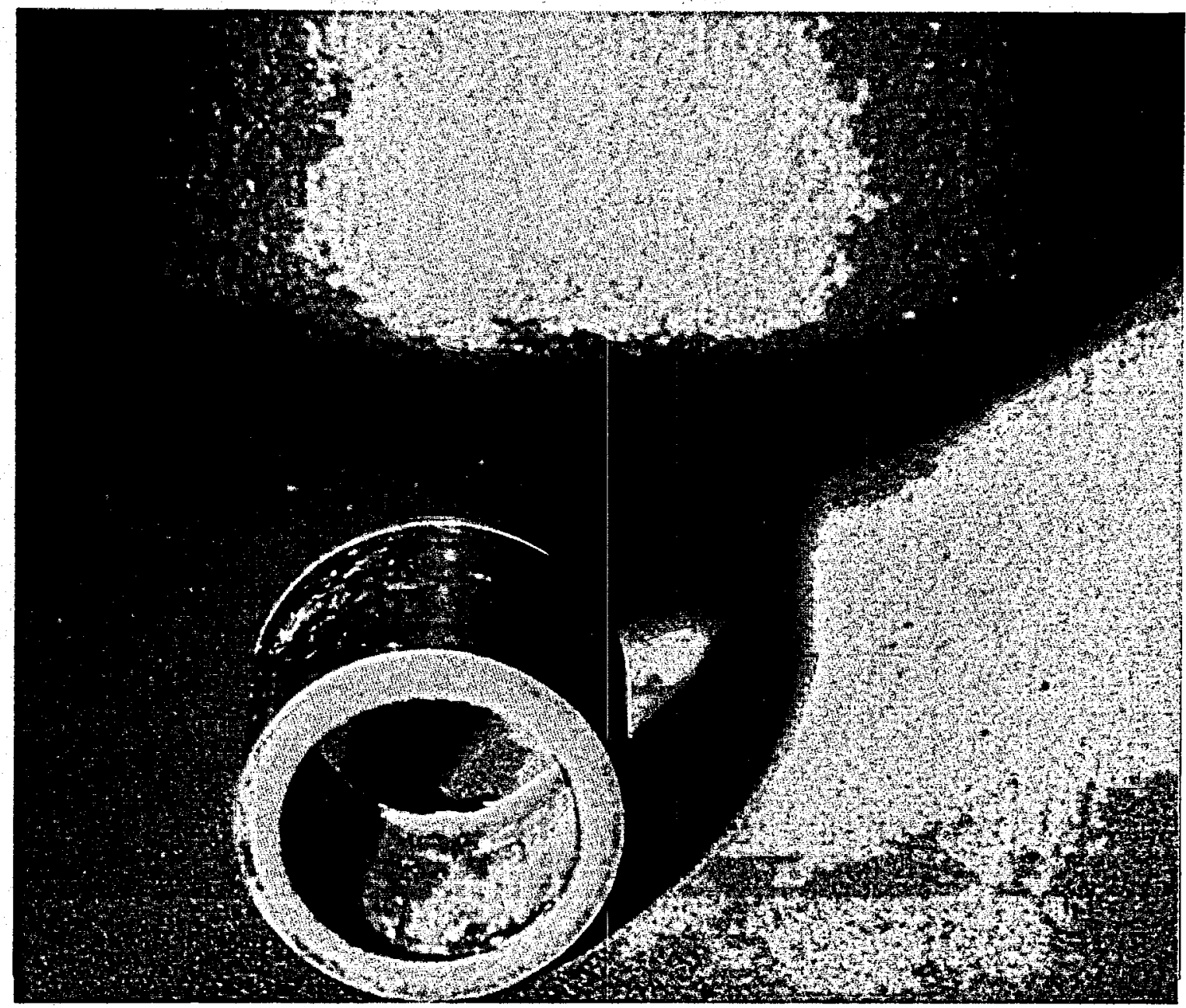

Fig. 9. Sample treated with 4 psia of $\mathrm{CF}_{3}$ at $75^{\circ} \mathrm{F}$ for $105 \mathrm{~d}$.

radiation fell to below the lower limit of detection of the beta meter by $9 / 16 / 92$. Sample 3-7 is an exception because of the unusually high beta emissions recorded. Sample 3-7 was treated in a reactor that did not contain $\mathrm{NaF}$ pellets; and during the 93.7-d treatment period, enough beta-emitting ${ }^{234} \mathrm{Th}$ formed to make the reactor walls and a copper test coupon radioactive above acceptable decontamination levels. These emissions fell to $9000 \mathrm{dpm} / 100 \mathrm{~cm}^{2}$ by $8 / 11 / 92$ and then further decreased to $3000 \mathrm{dpm} / 100 \mathrm{~cm}^{2}$ by $9 / 16 / 92$ as shown in the table. Later, the emissions further decreased below the LLD of the Ludlum beta/gamma meter. This phenomenon was also observed in other cases in which $\mathrm{NaF}$ pellets were not present.

If $\mathrm{NaF}$ pellets were present, the $\mathrm{UF}_{6}$ was trapped by them shortly after it was generated, and the ${ }^{234}$ Th was contained by the pellets rather than precipitated from the gas onto other surfaces in the reactor. Whether or not NaF pellets are present, the ${ }^{234} \mathrm{Th}$ daughter product will decay fairly rapidly once the ${ }^{238} \mathrm{U}$ is removed. The NaF pellets were obtained originally for the reasons listed here.

- At the beginning of the experiments, the possibility was considered that the $\mathrm{UF}_{6}$ generated by the action of $\mathrm{ClF}_{3}$ might react with previously noncontaminated surfaces, 
Table 3. Summary of observed decrease in radioactive emissions

\begin{tabular}{|c|c|c|c|c|c|c|c|c|}
\hline \multicolumn{3}{|c|}{ Before treatment $t^{a}$} & \multicolumn{6}{|c|}{ After treatment } \\
\hline Sample & $\underset{(\mathrm{Apm})^{b, e}}{\text { Alpha }}$ & $\begin{array}{c}\text { Beta } \\
(\mathrm{dpm})^{c}\end{array}$ & Date & $\begin{array}{l}\text { Alpha } \\
\text { (dpm) }\end{array}$ & $\begin{array}{l}\text { Beta } \\
\text { (dpm) }\end{array}$ & Date & $\begin{array}{l}\text { Alpha } \\
\text { (dpm) }\end{array}$ & $\begin{array}{c}\text { Beta } \\
\text { (dpm) }\end{array}$ \\
\hline 3-3 & & & $5 / 14 / 92$ & $<L L D^{d}$ & 1,200 & $9 / 16,92$ & $<$ LLD & $<$ LLD \\
\hline 3-11 & & & $6 / 12 / 92$ & <LLD & 1,000 & $9 / 16 / 92$ & <LLD & <LLD \\
\hline $3-4$ & 10,800 & 155,000 & $8 / 11 / 92$ & <LLD & 1,000 & $9 / 16 / 92$ & <LID & <LLD \\
\hline $3-7$ & 8,300 & 145,000 & $8 / 11 / 92$ & $<$ LLD & 9,000 & $9 / 16 / 92$ & <LLD & 3,000 \\
\hline 3-9 & 8,300 & 140,000 & $8 / 11 / 92$ & <LLD & 1,000 & 9/16/92 & <LLD & LLD \\
\hline
\end{tabular}

The before-treatment readings are approximations because the tube sections were not split open until after treatment. Also, the alpha readings will be much lower than the true activity because a uranium deposit is self-shielding to alpha radiation.

Dpm means disintegrations/minute/100 $\mathrm{cm}^{2}$ (usually abbreviated dpm/100 $\mathrm{cm}^{2}$ ).

'Both the Ludlum alpha meter and the Ludlum beta-gamma meters read caunts per minute. The counts per minute readings must be multiplied by both an efficiency factor and a geometry factor to convert the readings to $\mathrm{dpm} / 100 \mathrm{~cm}^{2}$. The efficiency factor varies slightly with different instruments but is -8.3 for the alpha meter and $\sim 5$ for a beta-gamma meter. If the object being survejed is significantly smaller in area than the meter probe, the geometry factor is 1 for either meter type, and the object is called a point source. If the object is not significantly smaller in area than the probe, the geometry factor is 2 for the alpha meter and 6 for the beta-gamma meter; and the object is called a plane source. ${ }^{17}$ The lab samples are considered point sources, but the readings expressed as $d p m / 100 \mathrm{~cm}^{2}$ are well below the decontamination criteria of Sect. 4 even if the plane source multiplier were used.

${ }^{2} L L D$ means lower level of detection ( $-80 \mathrm{dpm} / 100 \mathrm{~cm}^{2}$ for alpha meter, $-800 \mathrm{dpm} / 100 \mathrm{~cm}^{2}$ for beta-gamma meter). The L.LD varies somewhat with the particular instrument.

thereby contaminating them. If such cross-contamination occurred, the $\mathrm{NaF}$ pellets would have been evaluated as a means of preventing it, but uranium was not observed to transfer to clean surfaces.

- The NaF pellets were also obtained to determine if removing the $\mathrm{UF}_{6}$ from the reaction gas would increase the reaction rate, but this objective was not evaluated enough to make any conclusions. Future experiments may evaluate this possibility.

The reduction of both alpha and beta emissions to below the LLD, as revealed by readings taken after treatment, indicated that the LTLT evaluation was very successful in removing virtually all uranium deposits (Table 3 ). The results are therefore considerably better than the decontamination criteria described in Sect. 4. To this point, all portions of the samples evaluated in our experiments could be decontaminated by the action of the gas alone if sufficient time were allowed for completion of the reaction. Since these results were obtained with $\mathrm{UO}_{2} \mathrm{~F}_{2}$ deposited on smooth copper tube, these results do not necessarily represent other uranium deposits on different substrate materials that may prove much less reactive to $\mathrm{ClF}_{3}$ and which could be located in areas where diffusion of the reactive gases is slow. 


\section{APPLICATION TO FULLSCALE DECONTAMINATION}

\subsection{FULLSCALE DECONTAMINATION EQUIPMENT}

Although the design of the full-scale equipment necessary to decontaminate cascade equipment will not be completed until FY 94 (if funds are available), consideration has been given to the preliminary design, which is illustrated in Fig. 10. The process steps for this application are summarized in Fig. 11. The item to be decontaminated (3), which could be an entire cell, would first be leak proofed to ensure gas-tightness. The process equipment would be connected to the item as illustrated in Fig. 10, and the roughing pump (7) would be used to evacuate the gases (air or nitrogen) from the decontamination item. The item would then be leak tested.

Since leak testing large-volume items is difficult, the best method may be to seal the item following evacuation and leave it for a month with a pressure gauge installed to determine if it leaks up. If such a long-term leak test were done, the process equipment would be disconnected and moved to allow processing of other items during the interim. Following leak testing, the equipment would be reconnected and a mixture of $F_{2}$ and nitrogen gas would be administered as a pretreatment to dry the item and to remove any highly reactive organic material before $\mathrm{ClF}_{3}$ is introduced. Since $\mathrm{F}_{2}$ reacts with uranium oxyfluorides at low temperatures much more slowly than does $\mathrm{ClF}_{3}$, this step will be a useful safety precaution against excessive $\mathrm{ClF}_{3}$ reaction with impurities in the item being decontaminated. The $\mathrm{F}_{2}$ and other gases would then be evacuated through a system to recycle unused $F_{2}$.

The item would be charged to subatmospheric pressure with $\mathrm{ClF}_{3}$ and sealed. The process equipment, which would be mounted on a trailer, would be disconnected and moved to other locations to process other items. After an extended time (possibly > 4 months), the process equipment would be reinstalled as shown in Fig. 10. The recirculating blower (6) would be used to force the gases around a loop that would include the item being treated (3), the gas analyzer (2), the NaF trap (4) for $\mathrm{UF}_{6}$ removal, and the fluorinating gas recycle system (5). Nitrogen may also be added to aid in the purging of the gases. The gas analyzer would indicate when the $\mathrm{UF}_{6}$ and fluorinating gas levels were low enough for evacuation through the roughing pump (7). The above concept of the full-scale decontamination equipment should be viewed as preliminary. The concept will likely be revised, and numerous important issues and details have not yet been addressed. The concept may be changed to allow the $\mathrm{UF}_{6}$ to be removed from the gas as it is generated. Safety reviews may also motivate changes and additions to the design. Listed here are important issues concerning the full-size equipment design and application that remain to be addressed.

- The ability to seal the equipment sufficiently to prevent excessive in-leakage of air over the extended process time must be demonstrated. The compressor seals are the most obvious source for in-leakage, and an efficient method for sealing them must be devised.

- If gas-phase decontamination is applied on a full-production basis, the large amounts of $\mathrm{ClF}_{3}$ used will make a recycle system very important. The recycle system must separate the $\mathrm{ClF}_{3}$ from the other reaction by-product gases for reuse. 


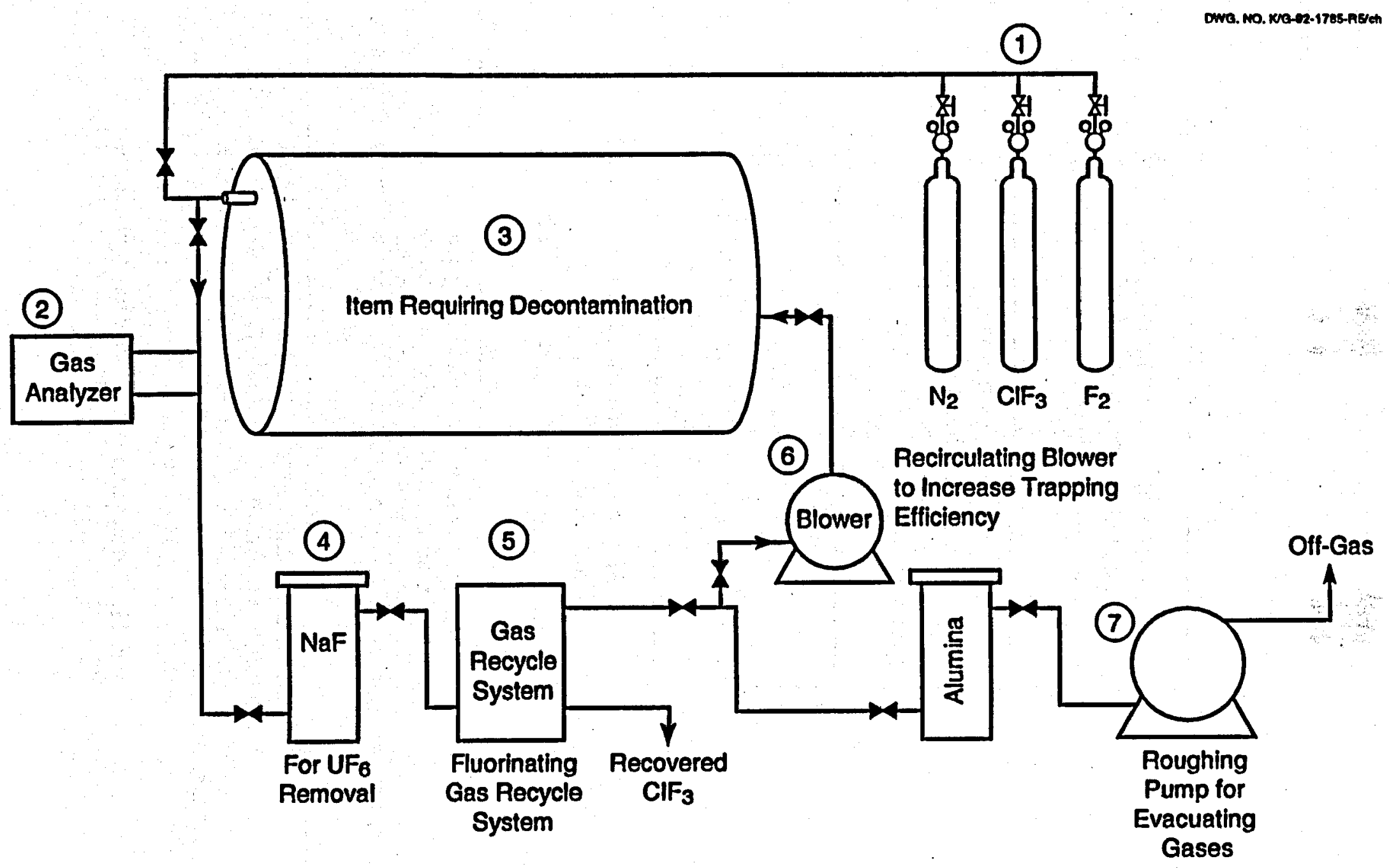

Fig. 10. Schematic of the full-scale LTLT equipment. 


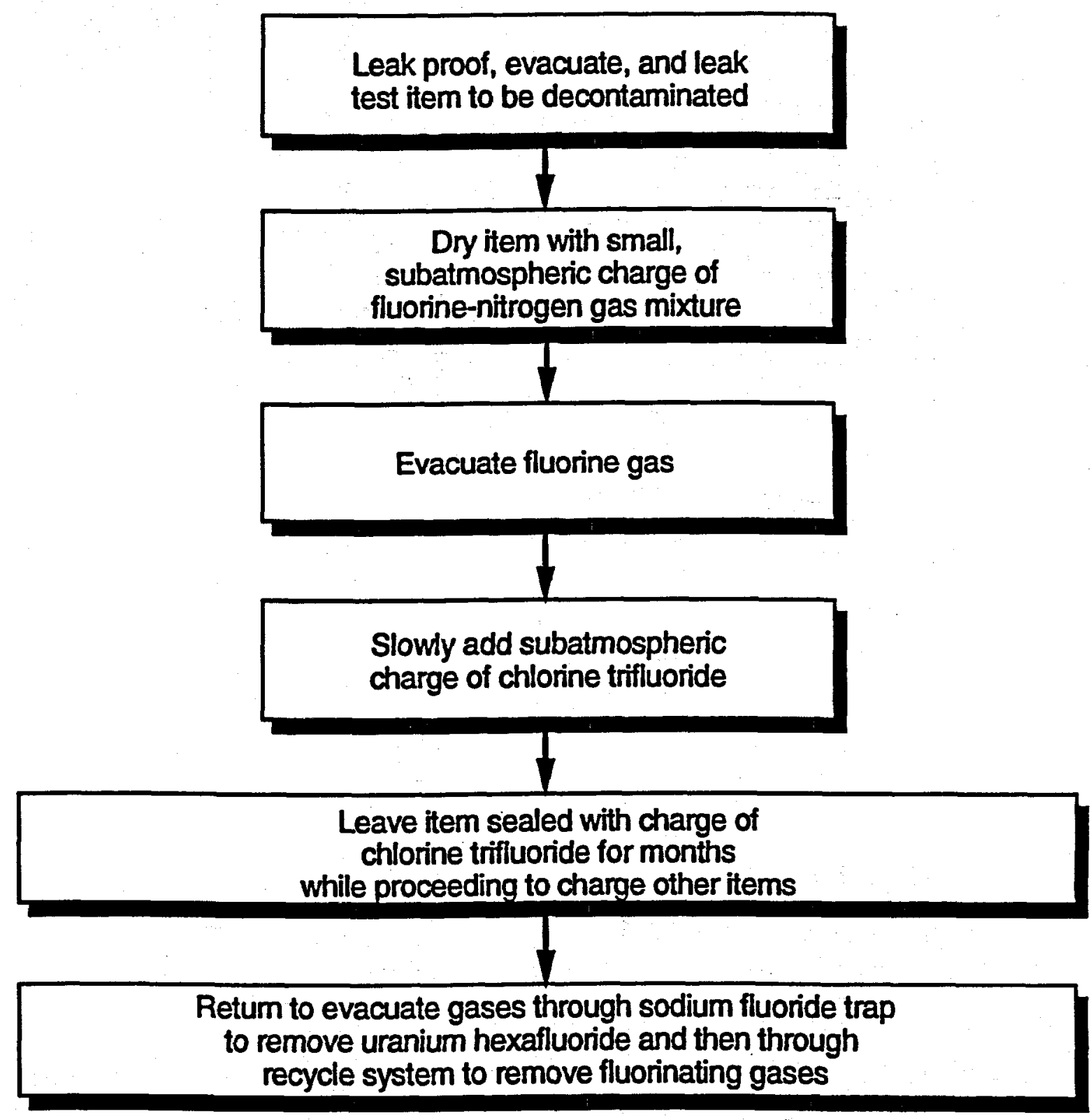

Fig. 11. Process steps for LTLT decontamination. 
- During a full-scale demonstration, the off-gases removed from the decontamination item could be trapped in alumina-soda lime traps, but gases such as oxygen and nitrogen will always remain, and they must be vented. Therefore, the details of handling the off-gases must be resolved for both demonstration and full-production cases.

\subsection{CONSIDERATIONS FOR SATISFACTORY DECONTAMINATION}

The goal of the decontamination process is to reduce radioactive emissions to levels that will satisfy the USAEC Regulatory Guide $1.86^{13}$ (Appendix A contains full details). Small lab samples are easier to decontaminate to release levels than are full-scale equipment, but the demonstrated ability to decontaminate the samples well below the levels specified in Regulatory Guide 1.86 is very significant even considering the advantage of scale. The uranium loading on the samples was approximately $1.2 \mathrm{~g}$ of elemental uranium/in. ${ }^{2}$. This is a much higher loading than would be expected in large equipment items. For example, if a small surge tank (6-ft diam, 18-ft length) had a loading of $1.2 \mathrm{~g}$ uranium/in. ${ }^{2}$ on the inside surfaces, $68.4 \mathrm{~kg}$ of uranium would be in the tank. This is a much greater amount than expected in the large majority of gaseous diffusion equipment, although some items have been identified with even larger amounts of uranium. (Most surfaces within gaseous diffusion equipment are not expected to have visible deposits.) Since the lab samples consisted entirely of $\mathrm{UO}_{2} \mathrm{~F}_{2}$ that had deposited in a copper seal exhaust line, the process effectiveness on other uranium deposits that have collected on other surfaces under different circumstances is uncertain. However, many of the other deposits are expected to be $\mathrm{UF}_{4} . \mathrm{ClF}_{3}$ has been shown to react with pure $\mathrm{UF}_{4}{ }^{14}$ Future lab studies will evaluate additional samples to help address this uncertainty.

The gas-phase process will not remove the nonvolatile radioactive daughters resulting from the decay of ${ }^{238} \mathrm{U},{ }^{234} \mathrm{U}$, and ${ }^{235} \mathrm{U}$, but in most cases, the daughters are not expected to be a serious problem. The ${ }^{234} \mathrm{Th}$ (half-life $24.1 \mathrm{~d}$ ) and ${ }^{234} \mathrm{~Pa}$ (half-life $1.2 \mathrm{~min}$ ) that result from the decay of ${ }^{238} U$ convert to very small amounts of ${ }^{234} U$ (half-life $2.45 \times 10^{5}$ years) in a reasonable time after the removal of the ${ }^{238} \mathrm{U}$. The ${ }^{244} \mathrm{U}$ can also be removed by gas-phase treatments. Portions of a cascade that contain heavy deposits of ${ }^{235} \mathrm{U}$ may pose a more serious problem because the short-lived ${ }^{231} \mathrm{Th}$ daughter (half-life $25.6 \mathrm{~h}$ ) of ${ }^{235} \mathrm{U}$ decays to ${ }^{231} \mathrm{~Pa}$ (halflife $3.5 \times 10^{4}$ years), which could accumulate in 60 years within a cascade to levels that could make obtaining release levels through gas-phase decontamination difficult at locations where unusually heavy deposits of ${ }^{235} \mathrm{U}$ were present. Also, the ${ }^{231} \mathrm{~Pa}$ migrated during the years that the gaseous diffusion cascades were in operation. $\mathrm{Pa}-231$ concentrations are slowly increasing in the high-enriched cascades (Appendix A contains additional details). Uranium-234 is concentrated with ${ }^{235} U$ in high-assay cascade areas. The ${ }^{234} U$ will be removed by gas-phase treatments, but the ${ }^{230} \mathrm{Th}$ daughter (half-life $7.52 \times 10^{4}$ years) of ${ }^{234} \mathrm{U}$ will remain. The ${ }^{230} \mathrm{Th}$ concentrations are also slowly increasing in the high-enriched cascades. The ${ }^{99} \mathrm{Tc}$ and ${ }^{237} \mathrm{~Np}$ that were introduced into portions of the cascades with uranium from recycled reactor tails poses an uncertainty, since good characterization does not exist for the amounts and distribution. Also, the effects of gas-phase treatments on the ${ }^{99} \mathrm{Tc}$ and ${ }^{237} \mathrm{~Np}$ are not known, although technetium compounds are known to be mobile. Technetium-99 and ${ }^{237} \mathrm{~Np}$ may prove troublesome in some cascade locations.

Considering the large volume of most cascade equipment items, in most cases more than enough $\mathrm{ClF}_{3}$ can be administered at subatmospheric pressure to allow complete reaction with the uranium deposits. This is illustrated by Table 4, which lists certain equipment and their approximate internal volume. The amount of $\mathrm{ClF}_{3}$ that would be needed to fill the volume to 4 psia at $80^{\circ} \mathrm{F}$ is indicated, as well as the amount of elemental uranium that theoretically 
could be removed if a $\mathrm{ClF}_{3}-\mathrm{UO}_{2} \mathrm{~F}_{2}$ reaction occurred. One of the objectives of a full-scale demonstration would be to determine the amount of time needed for a complete reaction of the $\mathrm{ClF}_{3}$ with the uranium deposit.

A price estimate of $\$ 23.80 / \mathrm{b}$ for $\mathrm{ClF}_{3}$ was recently received ${ }^{18}$ on the basis of a contract for $10,000 \mathrm{lb}$. This cost estimate, as well as considerations for reducing the amount of waste gases generated, underscores the importance of a $\mathrm{ClF}_{3}$ recycling method, which has not yet been developed.

Table 4. Amount of $\mathrm{CF}_{3}$ required to fill various equipment items to 4 psia at $80^{\circ} \mathrm{F}$

\begin{tabular}{|c|c|c|c|}
\hline Item & $\begin{array}{c}\text { Gas } \\
\text { volume } \\
\left(\mathrm{ft}^{3}\right)\end{array}$ & $\begin{array}{c}\text { Amount } \\
\text { of } \mathrm{ClF}_{3} \\
(\mathrm{~kg})\end{array}$ & $\begin{array}{c}\text { Amount of } \\
\text { elemental } \\
\text { uranium } \\
\text { theoretically } \\
\text { removed (kg) }\end{array}$ \\
\hline 000 converter & 2,690 & 77.9 & 100 \\
\hline 00 converter & 840 & 24.3 & 31.2 \\
\hline Size 2 converter & 190 & 5.5 & 7.1 \\
\hline 000 compressor & 452 & 13.1 & 16.8 \\
\hline 00 compressor & 180 & 5.2 & 6.7 \\
\hline Large surge tank & 1,300 & 37.6 & 48.4 \\
\hline Small surge tank & 510 & 14.8 & 19 \\
\hline
\end{tabular}

\section{ADVANTAGES OF THE LTLT GAS-PHASE PROCESS}

We expect that the LTLT process will minimize criticality and safeguard concerns, since the $\mathrm{UF}_{6}$ will remain a gas until trapped in geometrically safe traps, and since a toxic gas is less likely to be subject to theft than uranium solid or liquid form. Since the process does not require disassembly or movement of the equipment before decontamination, ALARA concerns are, perhaps, addressed in the best way. Since this in situ process uses the item being decontaminated as the process vessel for the decontamination treatment, requirements for new equipment and facilities are greatly minimized, and future decontamination requirements are also minimized since decontamination equipment and facilities must also eventually be decontaminated. This process also potentially allows simultaneous decontamination of entire cells in cascades that are in reasonably good condition. Gas phase is the only decontamination process that allows for the recovery of uranium in the form of $\mathrm{UF}_{6}$. This gas can be reused in operating cascades; consequently, considerable radioactive waste is avoided. 
The Ebasco cost estimate ${ }^{19}$ for decontaminating the USGDPs assumed that the gas-phase decontamination would be a necessary part of the overall process even though they did not expect it to totally decontaminate the equipment. They assumed that $\sim \$ 348 \mathrm{M}$ would be spent to build two furnace stand facilities: one for processing the high-enriched uranium process equipment, and a separate facility for low-enriched process equipment. They also assumed that the furnace stand process would remove $>90 \%$ of the uranium and that a high-pressure water decontamination process would be necessary as a second step. The cost of the highpressure water facilities was estimated at $\$ 174 \mathrm{M}$. If future lab testing with additional uranium contamination samples and full-size evaluations confirm the recent laboratory results, the expensive furnace stand facilities will not be needed since the lab results indicated that the LTLT process can remove the uranium deposits much more effectively than the furnace stand process as envisioned by Ebasco. In fact, large portions of the equipment might be decontaminated to release levels by the LTLT process alone, and portions not satisfactorily decontaminated could much more easily be treated in smaller high-pressure water facilities than those considered in the Ebasco estimate. For these reasons, the LTLT process has great potential for reducing facility costs.

The process may also considerably reduce operating costs. The LTLT process will be most efficient in buildings that have cascade cells that are reasonably intact, such as K-29, $\mathrm{K}-31$, and K-33 since the possibility of applying the process to perhaps entire cells at once would be more likely in those buildings. However, rough cost estimates (Appendix D) indicate that a single " 00 " $28,800-1 b$ converter may be decontaminated by the LTLT process for $\sim \$ 15,000$, which would be $\sim \$ 0.52 / \mathrm{b}$ in operating cost. 


\section{RECOMMENDATIONS}

Considering its favorable lab results, numerous operational advantages, and high payback potential, the LTLT process definitely should be continued on a laboratory scale, and we should begin designing the equipment needed for a full-scale demonstration. The lab scale studies should continue to investigate the important points listed here.

- The effectiveness of the $\mathrm{CF}_{3}$ treatments on uranium contamination found on various other substrate materials should be investigated; because, to this point, the lab samples were all $\mathrm{UO}_{2} \mathrm{~F}_{2}$ deposits on copper tube. Additional samples, such as uranium contamination on nickel-plated steel, barrier tube, bare steel, and other substrates should be evaluated.

- The effect of lower pressures of $\mathrm{CIF}_{3}$ and the effect of diluents, such as nitrogen and reaction by-products, on the reaction rate should be studied. This is important to help determine how long excess $\mathrm{ClF}_{3}$ could be reused before purification is necessary. Also, evaluating lower pressures of $\mathrm{ClF}_{3}$ is important since applying less $\mathrm{ClF}_{3}$ to a decontamination item will minimize recycle of the excess $\mathrm{ClF}_{3}$ and possibly alleviate safety concerns.

- The temperature dependency of the $\mathrm{ClF}_{3}-\mathrm{UO}_{2} \mathrm{~F}_{2}$ reaction should be further evaluated since the temperature of the cascade is $\angle 75^{\circ} \mathrm{F}$ much of the year.

Figure 12 contains a proposed schedule and cost estimate for a demonstration of the LTLT process on full-size cascade equipment such as a converter and a compressor. In FY 1992, the construction of the lab equipment was completed, and the experiments to date have been performed for $\$ 340 \mathrm{~K}$. According to this schedule, in FY 1993 the experiments would be continued and the design of the full-scale demonstration equipment would begin. The engineering disciplines at the K-25 Site would begin the engineering design phase during the latter part of the FY. The air permit and safety review processes would also be undertaken. The expected cost for FY 1993 would be \$1,000K. In FY 1994, the design phase would be completed and the construction phase would begin. These activities are expected to cost $\$ 2,000 \mathrm{~K}$ In FY 1995, the demonstration evaluation of several types of full-size equipment (previously mentioned in this Section) would begin. The demonstration activities would basically conclude in late FY 1995, except for the drafting of the report. Technology transfer activities would also begin in late FY 1995. The FY 1995 activities are expected to cost $\sim \$ 1,500 \mathrm{~K}$. In FY 1996, the final report and technology transfer activities would be completed at an expected cost of $\$ 225 \mathrm{~K}$. We estimate that the cost of the entire project will be $\$ 5,095 \mathrm{~K}$ 
DWG. NO. KO-P2-2507ARAA

\begin{tabular}{|c|c|c|c|c|c|c|}
\hline Activity & FY 91 & FY 92 & FY 93 & FY 94 & FY 95 & FY 96 \\
\hline \multicolumn{7}{|l|}{ Lab-scale apparatus construction } \\
\hline \multicolumn{7}{|l|}{ Hood permit exemption } \\
\hline \multicolumn{7}{|l|}{ Lab-scale experiments } \\
\hline \multicolumn{7}{|l|}{ Full-scale mobile system design } \\
\hline \multicolumn{7}{|l|}{ Air permit, EH\&S review, Engineering } \\
\hline \multicolumn{7}{|l|}{ Full-scale mobile system construction } \\
\hline \multicolumn{7}{|l|}{ Full-scale mobile system tests } \\
\hline \multicolumn{7}{|l|}{ Documentation and technology transfer } \\
\hline Present and future costs ( $\$$ thousands) & & $\$ 340 \mathrm{~K}$ & $\$ 1,000 \mathrm{~K}$ & $\$ 2,000 \mathrm{~K}$ & $\$ 1,500 \mathrm{~K}$ & $\$ 255 \mathrm{~K}$ \\
\hline
\end{tabular}

$\Delta$ Major decision point

a The total cost for the project is estimated to be $\$ 5,095 \mathrm{~K}$

Fig. 12. Gas-phase demonstration schedule and cost. 


\section{CONCLUSIONS}

Recent laboratory experiments have shown that heavy uranium deposits can be removed from cascade samples by reaction with $\mathrm{ClF}_{3}$ gas at subatmospheric pressure (4 psia) and at a temperature of $\sim 75^{\circ} \mathrm{F}$. The uranium deposits were $\mathrm{UO}_{2} \mathrm{~F}_{2}\left(\sim 1.3 \mathrm{~g}\right.$ uranium/in. $\left.{ }^{2}\right)$ that had formed inside \%-in. copper seal exhaust tubing in the K-33 cascade. Enough uranium was removed to reduce radioactive emissions to below the levels for unrestricted release, as specified in USAEC Regulatory Guide 1.86 . At $\sim 75^{\circ} \mathrm{F}$, the required treatment time was $<105 \mathrm{~d}$. The reaction rate was observed to be higher at temperatures $>75^{\circ} \mathrm{F}$; however, the reaction rate at $120^{\circ} \mathrm{F}$ exceeded the one at $150^{\circ} \mathrm{F}$, indicating an unusual temperature dependency. Practically, this means that at lower temperature ranges, a small amount of heat could provide better reaction rates than a greater amount of heat. The favorable results at low temperature indicate that heated enclosures (furnace stands) may not be necessary to decontaminate gaseous diffusion equipment by gas-phase treatments and strongly suggest that an LTLT approach should be further investigated. The LTLT treatment would involve sealing a subatmospheric charge of $\mathrm{ClF}_{3}$ gas in the gaseous diffusion equipment and allowing the $\mathrm{ClF}_{3}$ to react with the uranium deposits for an extended time.

Since only one type of uranium deposit that had formed in copper tubing was evaluated in this series of tests, additional experiments are needed to evaluate additional uranium contamination on other metal surfaces, such as nickel plate, barrier tube, and bare steel. The lab studies should also investigate the effect of process variables and diluents on the reaction rate. Listed here are some important issues that must be addressed before the practicality of the LTLT process can be evaluated.

- Gaseous diffusion equipment will contain various types of uranium contamination that have been deposited on various metals of various geometries; some of the equipment will have cracks and narrow passages. Therefore, the effectiveness of the LTLT process must be evaluated in a full-scale demonstration.

- The ability to sufficiently seal the contaminated equipment, especially the compressors, must be demonstrated.

- The full-scale decontamination equipment must be designed to allow for effective recycling of the $\mathrm{ClF}_{3}$ and venting of the off-gases.

- The extent to which the ${ }^{99} \mathrm{Tc}$ and daughters of ${ }^{234} \mathrm{U}$ and ${ }^{235} \mathrm{U}$ will impede successful decontamination probably cannot be fully answered until after radiological characterization of the cascades.

- A method for determining the process effectiveness in full-scale application must be formulated and executed.

Since the LTLT method is an in situ process, the payback potential is great. The process meets ALARA concerns in the best possible way, since the process does not require disassembly or movement of the equipment before decontamination. Because the $\mathrm{UF}_{6}$ removed by the process will remain in gas form until trapped in geometrically safe traps, criticality concern will be minimized. In the Ebasco study it was assumed that gas-phase 
decontamination would be necessary to minimize ALARA concerns, even though it was also assumed that the equipment would have to be moved into a furnace stand. In addition, it was assumed that after this pretreatment, a second decontamination method would have to be applied. The LTLT process represents a tremendous savings compared with the furnace stand process, since $>\$ 348 \mathrm{M}$ would be saved on the direct cost of the furnace stand facilities alone. Indirect cost reductions could amount to $\$ 399 \mathrm{M}$ in additional savings. Since entire cells of equipment could be potentially decontaminated at once by the LTLT process, large operating cost reductions are also possible. 


\section{REFERENCES}

1. R. D. Bundy and E. B. Munday, "Investigation of Gas-Phase Decontamination of Internally Radioactively Contaminated Gaseous Diffusion Process Equipment and Piping," presented at the 84th Annual Meeting, Air and Waste Management Association, 91-25.1, Pittsburgh, June 1991.

2. D. C. Goodland, unpublished data, September 1957.

3. L. B. Asprey, S. A. Kinkead, and P. G. Eller. "Low-Temperature Conversion of Uranium Oxides to Uranium Hexafluoride Using Dioxygen Difluoride," Nuclear Technology 73, 69-71 (April 1986).

4. D. C. Goodland and R. P. Levey, Jr., unpublished data, November 1952.

5. D. C. Goodland, unpublished data, April 1953.

6. Gesellschaft für Kernforschung M.B.H., "Method of Removal of Solid Reduction Products of Uranium Hexafluoride in Plants Handling Uranium Hexafluoride," British patent (London Office) 1,473,075, January 7, 1976.

7. E. J. Barber, Martin Marietta Energy Systems, Inc., Oak Ridge K-25 Site, personal communication to E. B. Munday, Martin Marietta Energy Systems, Inc., Oak Ridge K-25 Site, November 1989.

8. J. F. Ellis and C. W. Forrest, "Some studies in the Inorganic Chemistry of the Reaction Between Uranyl Fluoride with Chlorine Trifluoride," Journal of Inorganic Nuclear Chemical 16, 150-3 (1960).

9. R. C. Shrewsberry and E. L. Williamson, "Chemistry of the Chlorine Trifluoride Uranyl Fluoride Reaction," Joumal of Inorganic Nuclear Chemistry 28, 2535-2539 (1966).

10. E. J. Barber, Martin Marietta Energy Systems, Inc., Oak Ridge K-25 Site, personal communication to E. B. Munday, Martin Marietta Energy Systems, Inc., Oak Ridge K-25 Site, September 1992.

11. R. L. Farrar, Jr., Handling of Chlorine Trifluoride and the Chemistry of the Chlorine Oxides and Oxyfluorides, K-1416, Union Carbide Nuclear Company, Oak Ridge Gaseous Diffusion Plant, November 1960.

12. R. H. Reiner, J. P. Fry, and E. C. Angel, unpublished data, February 1988.

13. "Termination of Operating Licenses for Nuclear Reactors," in Regulatory Guide 1.86, USAEC Directorate of Regulatory Standards, June 1974.

14. V. Y. Labaton, "The Fluorides of Uranium-IV," J. Inorganic Nuclear Chemistry 10, 86 (1959).

15. "Mathematical Equations Used in Radioactive Decay Problems," in CRC Handbook of Radiation Measurement and Protection, Section A, Vol II: Biological and Mathematical Information, ed. A. Brodsky, CRC Press, Inc., 1982.

16. E. K. Hyde, I. Perlman, and G. T. Seaburg, The Nuclear Properties of the Heary Elements, Vol. II, Prentice-Hall, Inc., New Jersey, 1964.

17. Scot Wical, Martin Marietta Energy Systems, Inc., Oak Ridge K-25 Site Health Physics Department, personal communication to E. B. Munday, Martin Marietta Energy Systems, Inc., Oak Ridge K-25 Site, September 1992.

18. Joe Murphy, Air Products and Chemicals, Inc., Allentown, Pa., personal communication to E. B. Munday, Martin Marietta Energy Systems, Inc., the Oak Ridge K-25 Site, September 1992. 
19. Ebasco Services, Environmental Restoration of the Gaseous Diffusion Plants, Vols. 1 and 2, prepared under contract with U.S. Department of Energy, Office of Uranium Enrichment, Oak Ridge, Tenn., October 1991. 


\section{ACRONYMS, INITIALISMS, AND CHEMICAL FORMULAS}

\begin{tabular}{|c|c|}
\hline 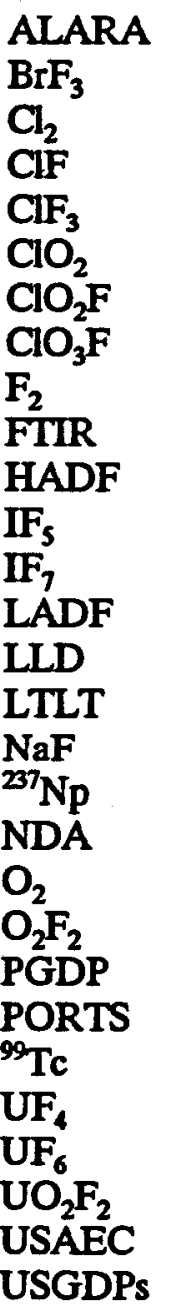 & $\begin{array}{l}\text { as low as reasonably achievable } \\
\text { bromine trifluoride } \\
\text { chlorine } \\
\text { chlorine fluoride } \\
\text { chlorine trifluoride } \\
\text { chlorine dioxide } \\
\text { chloryl fluoride } \\
\text { chlorine trioxyfluoride } \\
\text { fluorine } \\
\text { Fourier Transform Infrared Spectrometer } \\
\text { high-assay decontamination facility } \\
\text { iodine pentafluoride } \\
\text { iodine heptafluoride } \\
\text { low-assay decontamination facility } \\
\text { lower level of detection } \\
\text { long term, low temperature } \\
\text { sodium fluoride } \\
\text { neptunium } \\
\text { nondestructive analysis } \\
\text { oxygen } \\
\text { dioxygen difluoride } \\
\text { Paducah Gaseous Diffusion Plant } \\
\text { Portsmouth Gaseous Diffusion Plant } \\
\text { technetium } \\
\text { uranium tetrafluoride } \\
\text { uranium hexafluoride } \\
\text { uranyl fluoride } \\
\text { U.S. Atomic Energy Commission } \\
\text { U.S. gaseous diffusion plants }\end{array}$ \\
\hline
\end{tabular}



Table A.1. Acceptable surface decontamination levels ${ }^{a}$

\begin{tabular}{|c|c|c|c|}
\hline Nuclides $^{b}$ & Average $^{c d}$ & Maximumse & Removable $^{\text {ef }}$ \\
\hline $\begin{array}{l}\text { Natural uranium, } \\
{ }_{25} \mathrm{U},{ }^{28} \mathrm{U} \text {, and } \\
\text { associated decay } \\
\text { products }\end{array}$ & $5,000 \mathrm{dpm} \alpha / 100 \mathrm{~cm}^{2}$ & $\begin{array}{l}15,000 \mathrm{dpm} \\
\alpha / 100 \mathrm{~cm}^{2}\end{array}$ & $\begin{array}{l}1,000 \mathrm{dpm} \\
\alpha / 100 \mathrm{~cm}^{2}\end{array}$ \\
\hline 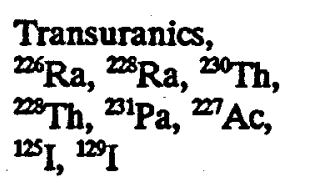 & $100 \mathrm{dpm} / 100 \mathrm{~cm}^{2}$ & $300 \mathrm{dpm} / 100 \mathrm{~cm}^{2}$ & $20 \mathrm{dpm} / 100 \mathrm{~cm}^{2}$ \\
\hline $\begin{array}{l}\text { Natural thorium, } \\
{ }^{252} \mathrm{Th},{ }^{90} \mathrm{Sr},{ }^{203} \mathrm{Ra}, \\
{ }^{214} \mathrm{Ra},{ }^{22} \mathrm{U},{ }^{126} \mathrm{I},{ }^{131} \mathrm{I},\end{array}$ & $1,000 \mathrm{dpm} / 100 \mathrm{~cm}^{2}$ & $3,000 \mathrm{dpm} / 100 \mathrm{~cm}^{2}$ & $200 \mathrm{dpm} / 100 \mathrm{~cm}^{2}$ \\
\hline $\begin{array}{l}\text { Beta-gamma } \\
\text { emitters (nuclides } \\
\text { with decay modes } \\
\text { other than alpha } \\
\text { emission or } \\
\text { spontaneous } \\
\text { fission) except "Sr } \\
\text { and others noted } \\
\text { above }\end{array}$ & $\begin{array}{l}5,000 \mathrm{dpm} \\
\beta \gamma / 100 \mathrm{~cm}^{2}\end{array}$ & $\begin{array}{l}15,000 \mathrm{dpm} \\
\beta \gamma / 100 \mathrm{~cm}^{2}\end{array}$ & $\begin{array}{l}1,000 \mathrm{dpm} \\
\beta \gamma / 100 \mathrm{~cm}^{2}\end{array}$ \\
\hline
\end{tabular}

'Table information taken from the U.S. Atomic Energy Commission Regulatory Guide, "Termination of Operating Licenses for Nuclear Reactors," Regulatory Guide 1.86, Directorate of Regulatory Standards, June 1974.

'Where surface contamination by both alpha- and beta-gamma-emitting nuclides exists, the limits established for alpha- and beta-gamma-emitting nuclides should apply independently.

'As used in this table, dpm (disintegrations per minute) means the rate of emission by radioactive material as determined by correcting the counts per minute observed by an appropriate detector for background, efficiency, and geometric factors associated with the instrumentation.

${ }^{d}$ Measurements of average contamination should be averaged over more than $1 \mathrm{~m}^{2}$. For objects of less surface area, the average should be derived for each subject.

The maximum contamination level applies to an area of not more than $100 \mathrm{~cm}^{2}$.

The amount of removable radioactive material per $100 \mathrm{~cm}^{2}$ of surface area should be determined by wiping that area with dry filter or soft absorbent paper, applying moderate pressure, and assessing the amount of radioactive material on the wipe with an appropriate instrument of known efficiency. When removable contamination on objects of less surface area is determined, the pertinent levels should be reduced proportionally and the entire surface should be wiped. 

Appendix B

\section{ADDITIONAL DATA AND PROCEDURAL DETAIIS}

\section{INTRODUCTION}

The laboratory work to date has focused on providing experimental evidence that supports the feasibility of in-situ low-temperature gas-phase decontamination, employing $\mathrm{ClF}_{3}$ to completely refluorinate solid uranium deposits to volatile $\mathrm{UF}_{6}$. The principal assurance of reaction completeness was percent uranium removed, determined by gravimetric analysis and radiation survey before and after gas exposure. The experiments were not designed nor intended for examination of reaction kinetics or mechanism. Nonetheless, in order to provide as complete a report as possible, an effort was made to extract the available data and attempt to quantify the results in the best manner possible considering the experimental limitations. The results presented are not intended as absolute rates or mechanisms, simply relative comparisons of data obtained during this limited feasibility study. Future work can be designed, if so desired, to obtain more definitive models for predicting reaction rates (i.e., the time necessary for complete recovery of uranium), quantity of fluorinating agent required per unit uranium, and reaction products expected under conditions anticipated during full-scale gas-phase decontamination of gaseous diffusion process equipment.

\section{SAMPLE CHARACTERIZATION} here.

Uranium deposits were selected for this feasibility study based on the few criteria given

- A deposit of $\mathrm{UO}_{2} \mathrm{~F}_{2}$ was desired. As mentioned in this report, it is believed that up to $80 \%$ of the uranium deposited in the cascade is in the form of $\mathrm{UO}_{2} \mathrm{~F}_{2}$, deposited on metal fluoride films from the hydrolysis of $\mathrm{UF}_{6}$ due to moist air inleakage during (and after) cascade operations.

- Preferably, the environment in which the compound was deposited could be deduced based on its location in the cascade and the deposit could be identified as "typical."

- Because a predefined experimental reaction system existed, the component size and the quantity of deposit ( $g$ of uranium) was restricted. Small process equipment was preferred to alleviate concerns regarding cutting large pieces.

The cascade sample selected was a continuous length of compressor seal exhaust line of \%/-in. copper pipe, which reportedly had been purged, backfilled, and maintained with an atmosphere of dry nitrogen. The pipe contained a quantified deposit measured by highresolution gamma-spectroscopy. Process knowledge led to plausible speculation that the deposit was $\mathrm{UO}_{2} \mathrm{~F}_{2}$, produced by $\mathrm{UF}_{6}$ hydrolysis due to moist air inleakage into a $\mathrm{UF}_{6}$ and dry nitrogen gas stream. The cascade sample was extracted from the K-33 building, unit 3, cell 5, stage 8 compressor. Four sections of pipe were crimped and cut, with average uranium loading of $1.3-1.5 \mathrm{~g} / \mathrm{in}$. at $\sim 0.73 \% \pm 0.15 \%{ }^{235} \mathrm{U}$ as estimated by NDA measurement. 
However, subsequent inspection of the sample in the laboratory revealed a somewhat heavier $(\sim 2 \times)$, and variable, distribution of the deposit. $X$-ray diffraction of a single yellow chip extracted from pipe section 3 identified nearly pure $\mathrm{UO}_{2} \mathrm{~F}_{2}$ crystallite with an amorphous background. Chemical analysis of approximately $0.5 \mathrm{~g}$ of chips by a modified Davies-Gray titration $^{\mathrm{B}-1}$ revealed $70.36 \%$ total uranium (theoretical $77.3 \%$ for anhydrous material), implying $\mathrm{UO}_{2} \mathrm{~F}_{2}$ with -0.65 waters of hydration $\left(\mathrm{UO}_{2} \mathrm{~F}_{2} \bullet 0.65 \mathrm{H}_{2} \mathrm{O}\right)$. No attempt was made to remove hydrated or absorbed water from the deposit before sample analysis or prior to refluorination, since the experimental intent was to investigate samples typical of the cascade. This is in contrast to the referenced work in section three, ${ }^{8,9}$ in which the investigators dried the $\mathrm{UO}_{2} \mathrm{~F}_{2}$ to $0.6 \%$ and $0.03 \%$ water, respectively $\left(\mathrm{UO}_{2} \mathrm{~F}_{2} \bullet \leq 0.1 \mathrm{H}_{2} \mathrm{O}\right)$. A single determination of surface area by the BET (Brunauer, Emmett, and Teller) method using nitrogen as adsorbate gave an average surface area of $0.21 \pm 0.02 \mathrm{~m}^{2} / \mathrm{g}$ using $0.79 \mathrm{~g}$ of chips. Experimental procedure for surface analysis required the heating of the sample to $75^{\circ} \mathrm{C}$ under a helium bleed, then evacuation for $2 \mathrm{~h}$ prior to pressurization with nitrogen. Previous studies $^{8,9}$ had employed samples measured at 12.2 and $6.09 \mathrm{~m}^{2} / \mathrm{g}$; however, the investigators had prepared the $\mathrm{UO}_{2} \mathrm{~F}_{2}$ in the laboratory with water in stoichiometric or excess quantities, then dried to near anhydrous material. Presumably, our samples were produced with $\mathrm{UF}_{6}$ in great excess to the available water. Analysis had shown the cascade samples to be hydrated, corroborated by the weight stability of the deposit with respect to atmosphere during preexposure weight determination. While some of the absorbed water was probably volatized during preparative surface area analysis procedures, available surface sites were probably reduced compared with anhydrous $\mathrm{UO}_{2} \mathrm{~F}_{2}$. Due to the cascade samples appearance as a stable hydrated $\mathrm{UO}_{2} \mathrm{~F}_{2}$ no attempt was made to handle the samples in an inert gas buffer or drybox prior to $\mathrm{CFF}_{3}$ exposure.

\section{EXPERIMENTAL PROCEDURE}

Before initiating experiments with cascade samples, the reaction systems were dried with $\mathrm{ClF}_{3}$, then passivated with $\mathrm{F}_{2}$ at $250^{\circ} \mathrm{F}$ to provide a protective surface fluoride film to maintain fluoride availability for the cascade sample. The nickel reactor vessel installed in the flow loop had been employed extensively in previous gas-phase reaction studies. The reactor required several intensive $\mathrm{ClF}_{3}$ treatments to remove deposited and/or absorbed surface uranium as observed by monitoring the treatment gas stream with the FTIR. The lower detection limit for uranium (as $\mathrm{UF}_{6}$ gas) with the FTIR in the flow loop system was $\sim 5 \mathrm{mg}$. If no $\mathrm{UF}_{6}$ was detected in the infrared spectrum during $\mathrm{CIF}_{3}$ pretreatment, this indicated that all $\mathrm{UF}_{6}$ volatized during an experiment would be derived from the refluorination of the cascade sample, and not recovered from the reactor walls. Additional reaction species identified by infrared analysis included the fluorinating agent, $\mathrm{CF}_{3}$, and the products chloryl fluoride $\left(\mathrm{ClO}_{2} \mathrm{~F}\right), \mathrm{ClF}, \mathrm{ClO}_{3} \mathrm{~F}, \mathrm{HF}$ and $\mathrm{ClO}_{2}$, Pertechnetyl fluoride $\left(\mathrm{TcO}_{3} \mathrm{~F}\right)$, the ${ }^{99} \mathrm{Tc}$ species anticipated in some areas of the cascade, and the more volatile hexafluoride, $\mathrm{TcF}_{6}$, can also be identified by infrared analysis. No technetium was detected during this investigation. Diatomic compounds such as $\mathrm{F}_{2}$ oxygen $\left(\mathrm{O}_{2}\right)$, and chlorine $\left(\mathrm{Cl}_{2}\right)$ do not exhibit vibrational signatures over the wavelength examined $(4400-400 \mathrm{~cm}-1)$, and cannot be monitored by this technique. However, $\mathrm{Cl}_{2}$ and $\mathrm{O}_{2}$ may be assumed to be potential products of disassociation of the $\mathrm{ClO}_{2} \mathrm{~F}$ over extended time exposures. The $\mathrm{ClO}_{2} \mathrm{~F}$ concentration did not decrease with extended time exposures in our studies, and was still present in theoretical stoichiometric 
equivalents at reaction completion (i.e., molar equivalent to $\mathrm{UF}_{6}$ ). We do not believe we had significant quantities of $\mathrm{Cl}_{2}$ or $\mathrm{O}_{2}$ as product.

Calibration spectra of $\mathrm{UF}_{6}$ and $\mathrm{ClF}_{3}$ were acquired pure, in inert gas dilution, and as a mixture. Spectra were obtained both as a static mixture (after $\sim 30$ min mixing time) and as a dynamic gas stream. Spectra were collected by standard serial dilution techniques over the pressure range anticipated during the experiments, with the data fit using linear least squares. The calibrations provide the proportionality constant relating the partial pressure of a specific gas to the infrared absorbance of that gas at a known wavelength and known gas pathlength. Partial pressures of the reaction by-products were determined using calibration constants acquired from previous studies and compiled into an internally available reference source. ${ }^{\mathrm{B}-2}$

Each sample was cut to length (1.5 in. for flow loop, 0.5 in. for LTLT static reactor) immediately preceding insertion into the reaction vessel, and the remaining pipe end was resealed. No volatile vapors were observed. Each sample was weighed to milligram resolution. The latter flow loop samples and all static samples were surveyed for approximate alpha and beta/gamma radiation using a hand-held Ludlum counter. A few samples were photographed. Future studies will include photo documentation of each sample, in addition to the gravimetric and radiochemical analysis. After assurance of a cleaned vessel, (i.e., no $\mathrm{UF}_{6}$ present in the $\mathrm{ClF}_{3}$ cleanup gas stream), the flow loop was evacuated, purged with dry nitrogen, and backfilled to slightly greater than atmospheric pressure. Under a low flow dry nitrogen purge, the cascade sample was placed in a fluoride passivated monel holder which forced the gas flow through the sample pipe and inserted into the center of the reactor. Following closure of the vessel and nitrogen purge line, system pressure was allowed to equilibrate to ascertain vacuum integrity. The system was then evacuated, charged to 0.4 psia $F_{2}$ at room temperature to "dry" the sample and remove potential absorbed hydrocarbons from the outer pipe wall. Infrared analysis provided evidence that no UF $_{6}$ was volatized during any of these $F_{2}$ exposures. The flow loop was then charged to a total 4 psia with argon, gas stream circulation initiated, the sample "dried" for $-30 \mathrm{~min}$, and the gas stream monitored with the FTIR. No $\mathrm{UF}_{6}$ was evident during any drying pre-treatments. The $\mathrm{F}_{2}$ /argon mixture was then evacuated, and under approximate high-vacuum conditions a background spectrum of the evacuated gas cell was acquired. The background is used by the FTIR to ratio out any spectral contributions of the gas cell to the infrared spectra acquired during experimental analysis of the gas mix. For heated $\mathrm{ClF}_{3}$ exposures $\left(120\right.$ and $\left.150^{\circ} \mathrm{F}\right)$, an equal pressure of argon was circulated in the loop during temperature ramp-up and reactor equilibration.

When the reactor temperature was stabilized at experimental set-point, the evacuation system was closed and $\mathrm{ClF}_{3}$ injected to pressure at static conditions. Gas circulation was initiated, and a reference infrared spectrum of the gas stream was obtained. Subsequent spectra were acquired at periodic intervals during the refluorination, ratioed to the background spectrum and stored. The reference spectrum, indicative of the gas stream at time zero, was then spectrally subtracted from the sample spectrum. The resultant spectrum consisted of only product gas that was not present initially, and provided the data from which the partial pressure for the product gases $\left(\mathrm{UF}_{6}, \mathrm{ClO}_{2} \mathrm{~F}, \mathrm{ClF}, \mathrm{HF}\right.$ and $\left.\mathrm{ClO}_{3} \mathrm{~F}\right)$ was calculated. $\mathrm{ClF}_{3}$ partial pressure as a function of time was calculated from the original sample spectrum, after correction for baseline drift. Temperature, gas velocity and system pressures were observed and recorded as well. Gas circulation was maintained at an initial constant $(\sim 200$ standard $\mathrm{cm}^{3} / \mathrm{min}$ ) for all experiments, except during the initial $80^{\circ} \mathrm{F}$ exposure. No difference was detected in reaction rate due to an $\sim 10 \mathrm{x}$ greater flow rate. Because of the flow loop conductance, pressure at the FTIR gas cell $\left(\mathrm{P}_{2}\right.$ in Fig. 1) was $\sim 20 \%$ lower than the pressure 
at either end of the reactor vessel. This pressure drop was corrected during data calculations so that pressures reported reflect partial pressures at the reaction surface.

At reaction termination the recovered $\mathrm{UF}_{6}$ was cold-trapped, and the excess $\mathrm{ClF}_{3}$ and other product gases evacuated through the chemical trap. The flow loop was purged with dry nitrogen and backfilled to slightly greater than atmospheric pressure. At room temperature and with a slow dry $\mathrm{N}_{2}$ bleed the reactor vessel was opened and the cascade sample retrieved. The pipe was immediately weighed. If a visible residue remained, the weight continually increased. This would indicate a more anhydrous residue, with moisture taken up by the residue to reach the atmospherically stable hydrate. $\mathrm{X}$-ray diffraction of a single sample residue gave $\mathrm{UO}_{2} \mathrm{~F}_{2} \cdot 1.6 \mathrm{H}_{2} \mathrm{O}$. Typically, the residue would be physically separated from the copper substrate, and could be weighed individually. Together with the Davies-Gray titration $^{\mathrm{B}-1}$ of the pipe to determine total uranium residue, a differential weight was obtained that equaled the deposit weight. This weight, reported as percent deposit recovered, appears in the tabulated results. Due to a slight $(\sim+10 \%)$ systematic bias of total uranium identified in the infrared spectra, this percent deposit recovered was then used to correct the estimate of the $\mathrm{UF}_{6}$ partial pressure as a function of time.

\section{DISCUSSION}

Figure B.1 depicts the temperature dependence of the reaction of $\mathrm{ClF}_{3}$ and $\mathrm{UO}_{2} \mathrm{~F}_{2}$ at 4 psia, with the percent deposit remaining graphed as a function of time for the three temperatures examined in the flow loop. The two exposures at $80^{\circ} \mathrm{F}$ and the two exposures at $150^{\circ} \mathrm{F}$ were fairly reproducible for the exposure time examined with the higher temperature reaction predictably faster. The three exposures at $120^{\circ} \mathrm{F}$ were more varied, although two of the three were noticeably faster in terms of percent deposit recovered than the $150^{\circ} \mathrm{F}$ exposures. This peculiarity will be reexamined. Preliminary analysis of the results has failed to establish accurate models of the rate in a consistent manner, perhaps due to the complexity of the reaction with the hydrated $\mathrm{UO}_{2} \mathrm{~F}_{2}$ and the failure to adequately characterize such potential reaction parameters as surface area, and particle and/or crystallite size. A nonlinearity to the graph of percent deposit remaining vs time exists, suggesting that the reaction may occur in multiple phases.

Figure B.2 reveals with greater clarity the potential multiphasic nature of the reaction in terms of $\mathrm{ClF}_{3}$ consumed. Moles of $\mathrm{ClF}_{3}$ consumed are ratioed to the moles of $\mathrm{UF}_{6}$ recovered (i.e., the stoichiometry of the reaction) as a function of time. Initial consumption of the $\mathrm{ClF}_{3}$ is much greater than expected ( -2.5 to $5 \times$ theoretical), then slowly decreases before the molar ratio tends to level out and remain essentially constant to completion. It is thought that absorbed water, hydrated water, and $\mathrm{UO}_{2} \mathrm{~F}_{2}$ react initially and more rapidly, as noted by colleagues of Ellis and Forrest. ${ }^{8}$ The hydrated water and $\mathrm{UO}_{2} \mathrm{~F}_{2}$ then react a little more slowly until the water is converted, leaving a near anhydrous $\mathrm{UO}_{2} \mathrm{~F}_{2}$ deposit, with approximately the final $10 \%$ or so of the deposit recovered very slowly.

Although we were unable to unambiguously establish the overall reaction order and rate constants, we were able to establish a range of overall stoichiometries relevant to the present study. Data on the stoichiometry of the $\mathrm{CIF}_{3}-\mathrm{UO}_{2} \mathrm{~F}_{2}$ reaction in mol/mol of $\mathrm{UF}_{6}$ at experimental termination are presented in Table B.1. Gas samples representing two of the LTLT exposures (which did not include NaF traps) are included for comparison with the flow loop experiments. The initial $\mathrm{ClF}_{3}$ and the amount of $\mathrm{ClF}_{3}$ consumed are reported in $\mathrm{mol} / \mathrm{mol}$ of $\mathrm{UO}_{2} \mathrm{~F}_{2}$. Products tabulated are those that can be identified by infrared analysis, as discussed 


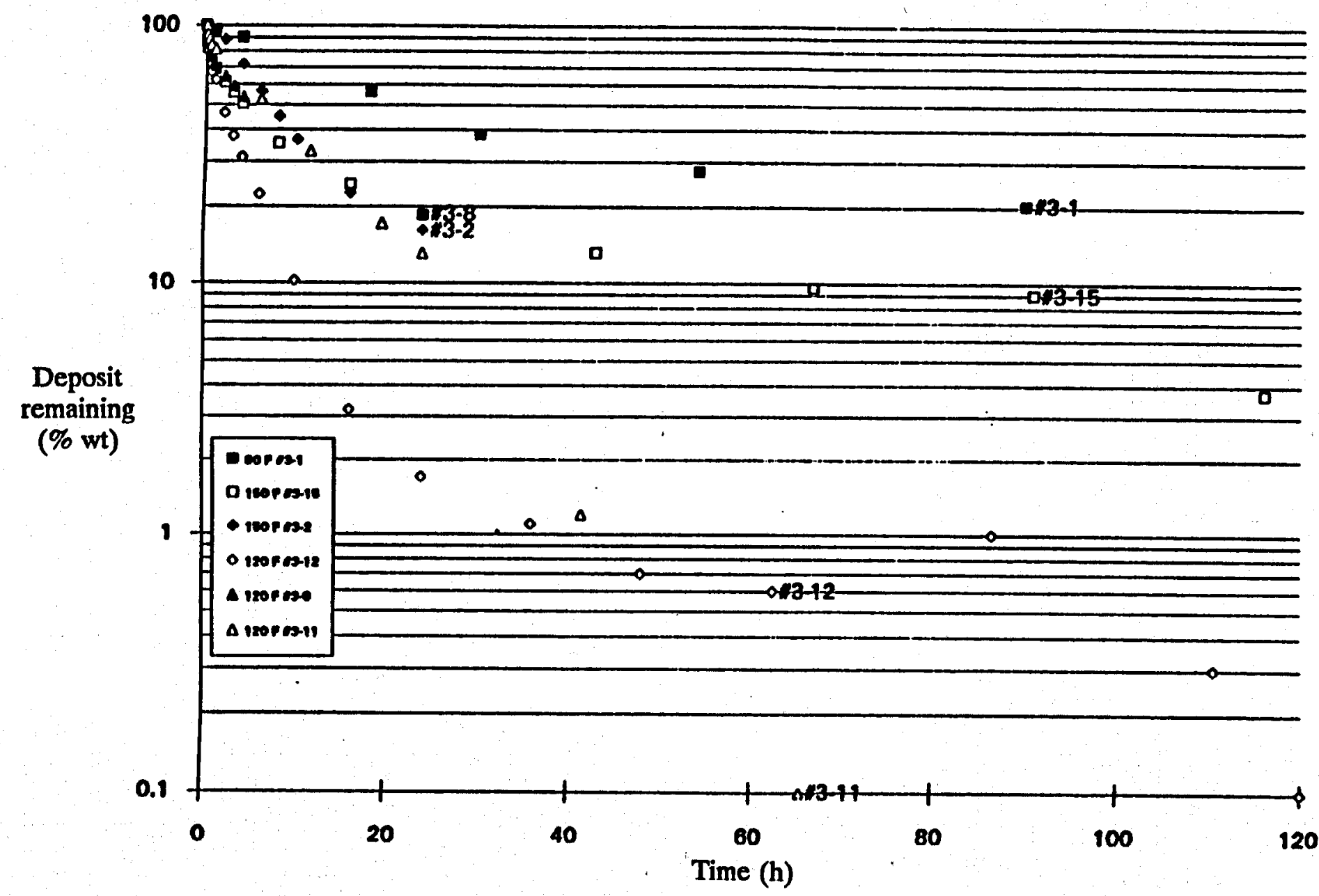

Fig. B.1. Temperature dependence for the reaction of $\mathrm{CF}_{3}$ and $\mathrm{UO}_{2} \mathrm{~F}_{2}$ at 4 psia at $80^{\circ} \mathrm{F}, 120^{\circ} \mathrm{F}$, and $150^{\circ} \mathrm{F}$. Each series represents a time exposure for a single sample in the flow loop. Data points represent UF $_{6}$ partial pressure determined by FTIR spectra which have been normalized to deposit differential weight determined gravimetrically. 


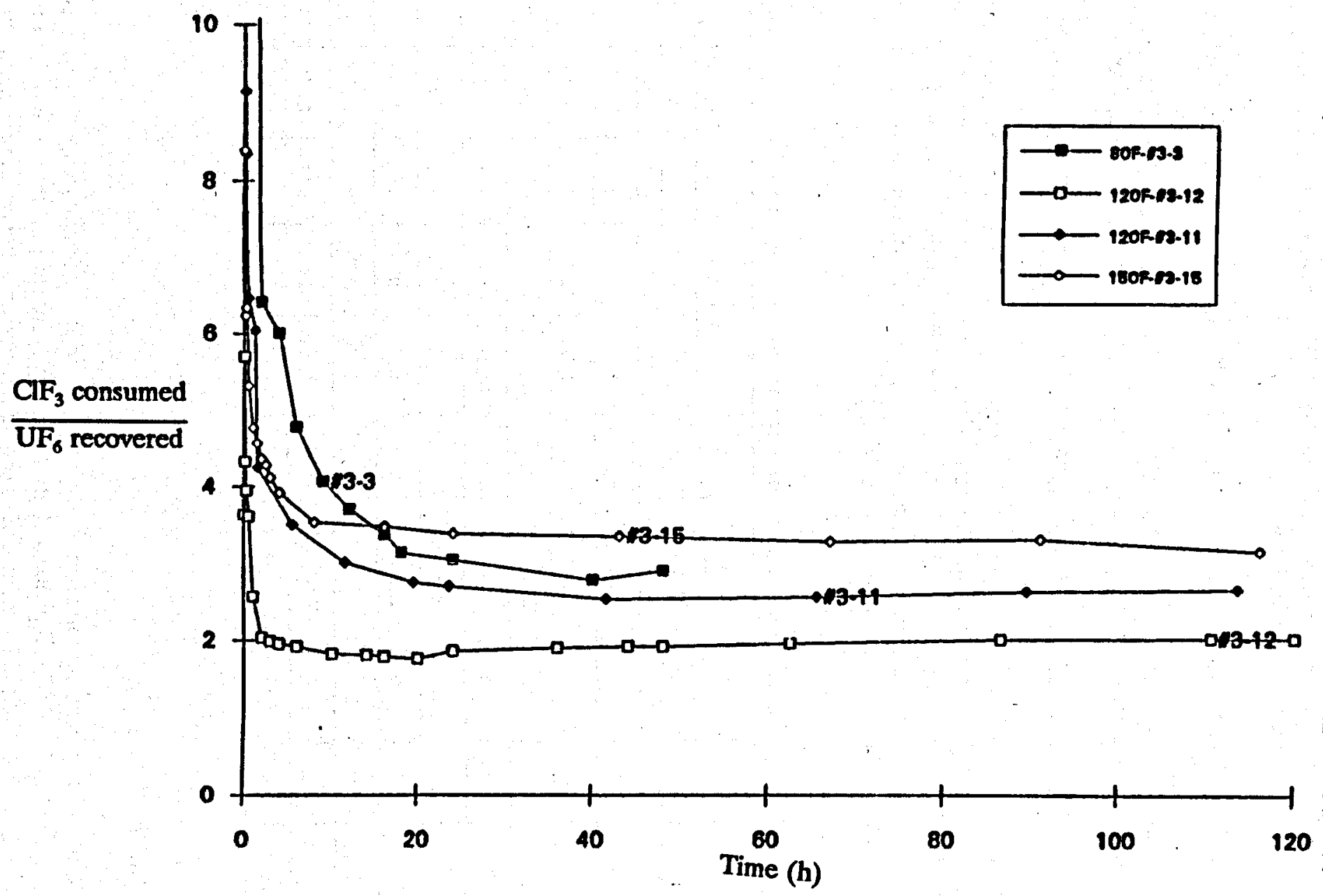

Fig. B.2 Ratio of the mol of $\mathrm{CFF}_{3}$ consumed to the mol of $\mathrm{UF}_{6}$ recovered for the reaction of $\mathrm{CF}_{3}$ and $\mathrm{UO}_{2} \mathrm{~F}_{2}$ at 4 psia and $80^{\circ} \mathrm{F}, 120^{\circ} \mathrm{F}$, and $150^{\circ} \mathrm{F}$. Each series represents a time exposure for a single sample in the flow loop. 
on page $\mathrm{B}-4$. It can be seen from the data that the overall experimental stoichiometry for the flow loop experiments with the hydrated $\mathrm{UO}_{2} \mathrm{~F}_{2}$ is similar to the referenced work discussed earlier, ${ }^{8,9}$ particularly the lower temperature studies by Ellis and Forrest. ${ }^{8} \mathrm{ClF}_{3}$ was in excess in all experiments, with an average $2.33 \mathrm{~mol}$ of $\mathrm{ClF}_{3}$ reacted per mol of $\mathrm{UO}_{2} \mathrm{~F}_{2}$ for an experimentally derived unbalanced equation:

$$
2.33 \mathrm{ClF}_{3}+\mathrm{UO}_{2} \mathrm{~F}_{2} \bullet x \mathrm{H}_{2} \mathrm{O} \rightarrow \mathrm{UF}_{6}+1.12 \mathrm{ClF}+0.86 \mathrm{ClO}_{2} \mathrm{~F}+0.25 \mathrm{HF}+0.015 \mathrm{ClO}_{3} \mathrm{~F}
$$

Slightly more $\mathrm{ClF}_{3}$ was consumed in the static reactors, an average of 3.07 moles per mole $\mathrm{UO}_{2} \mathrm{~F}_{2}$. By-products were also in greater proportion to the $\mathrm{UF}_{6}$ recovered, providing:

$$
3.07 \mathrm{ClF}_{3}+\mathrm{UO}_{2} \mathrm{~F}_{2} \bullet \mathrm{H}_{2} \mathrm{O} \rightarrow \mathrm{UF}_{6}+1.47 \mathrm{ClF}+1.07 \mathrm{ClO}_{2} \mathrm{~F}+0.58 \mathrm{HF}+0.028 \mathrm{ClO}_{3} \mathrm{~F}
$$

again, in unbalanced form. The nature of the experimental procedure employed on the LTLT reactors does not provide exact knowledge of time of complete deposit recovery. However, use of visual and gravimetric analysis, with Davies-Gray analysis of the decontaminated samples, does provide sufficient evidence that $\mathrm{ClF}_{3}$ is capable of complete refluorination of $\mathrm{UO}_{2} \mathrm{~F}_{2}$ produced under actual cascade conditions.

\begin{tabular}{|c|c|c|c|c|c|c|c|c|c|}
\hline \multirow[b]{2}{*}{ Sample } & \multirow{2}{*}{$\begin{array}{c}\text { Time } \\
\text { (d) }\end{array}$} & \multirow{2}{*}{$\begin{array}{c}\text { Temp } \\
\left({ }^{\circ} \mathrm{F}\right)\end{array}$} & \multirow{2}{*}{$\begin{array}{c}\text { Initial } \\
\text { reactant } \\
\text { (per mol } \\
\mathrm{UO}_{2} \mathrm{~F}_{2} \text { ) } \\
\end{array}$} & \multirow{2}{*}{$\begin{array}{c}\mathrm{UO}_{2} \mathrm{~F}_{2} \\
\text { reacted } \\
(\% \mathrm{wt})\end{array}$} & \multicolumn{4}{|c|}{ Products identified (per mol UF ) } & \multirow{2}{*}{$\begin{array}{c}\mathrm{CF}_{3} \\
\text { consumed } \\
\text { (per mol } \\
\mathrm{UO}_{2} \mathrm{~F}_{2} \text { ) } \\
\end{array}$} \\
\hline & & & & & CIF & $\mathrm{ClO}_{2} \mathrm{~F}$ & HF & $\mathrm{ClO}_{3} \mathrm{~F}$ & \\
\hline LTLT\#3-6 & 91.1 & 75 & 6.79 & 99.3 & 1.56 & 0.96 & 0.61 & 0.015 & 2.85 \\
\hline LTLT\#3-7 & 93.7 & 140 & 5.50 & 99.9 & 1.37 & 1.18 & 0.54 & 0.04 & 3.28 \\
\hline TL\#3-1 & 7.0 & 80 & 4.72 & 86.2 & 1.30 & 0.96 & 0.17 & 0.006 & 269 \\
\hline TL\#3-3 & 20 & 80 & 3.79 & 69.0 & 1.23 & 0.85 & 0.21 & 0.003 & 2.25 \\
\hline TL\#3-8 & 1.8 & 120 & 3.61 & 824 & 0.92 & 0.77 & 0.19 & 0.02 & 2.25 \\
\hline TL\#3-11 & 5.8 & 120 & 283 & 99.9 & 1.16 & 0.90 & 0.41 & 0.02 & 214 \\
\hline TL\#3-12 & 5.0 & 120 & 4.13 & 99.9 & 0.76 & 0.82 & 0.18 & 0.02 & 2.47 \\
\hline TL\#3-2 & 1.0 & 150 & 4.13 & 83.9 & 1.19 & 0.81 & 0.14 & 0.004 & 2.24 \\
\hline$T L \# 3-15$ & 4.8 & 150 & 3.00 & 96.3 & 1.25 & 0.89 & 0.48 & 0.03 & 2.27 \\
\hline
\end{tabular}

Table B.1. Observed stoichiometry at experimental termination

\section{CONCLUSION}

The gas-phase decontamination study has focused on providing experimental evidence of the feasibility of an LTLT process that can completely refluorinate uranium deposits to volatile $\mathrm{UF}_{6}$. The initial phase examined one type of deposit believed to represent the largest fraction of deposit contained in the process equipment. Evidence that the reaction of $\mathrm{ClF}_{3}$ and $\mathrm{UO}_{2} \mathrm{~F}_{2}$ will proceed to completion at low temperatures is presented, suggesting the concept of gas-phase decontamination as an economic advantage for the cleanup of gaseous 


\section{B-9}

diffusion process equipment. Future experimental efforts need to be pursued with additional uranium compounds deposited upon the various substrates employed in the diffusion process. Characterization of the deposits before refluorination of the sample would allow more detailed and complete analysis of the reaction, and presumably more definitive models for predicting the efficacy of gas-phase decontamination when employed in-situ on full-scale gaseous diffusion process equipment. 
Appendix B

\section{REFERENCES}

B-1. R. J. Jarabek, Transport Measurements of $U F_{6}$ Using a Precision Analysis for $U^{+4}$, K/PS-5017, 1984.

B-2. W. Schwab and R. L. Farrar, Oak Ridge Gaseous Diffusion Plant, unpublished, 1978. 
Appendix C

PERTINENT RADIOACTIVE DECAY INFORMATION 


\section{Appendix C \\ PERTINENT RADIOACTIVE DECAY INFORMATION}

Uranium ore contains three isotopes of uranium: ${ }^{238} \mathrm{U}(99.2930 \mathrm{wt} \%),{ }^{235} \mathrm{U}(0.7114 \mathrm{wt} \%)$, and ${ }^{234} \mathrm{U}(0.0054 \mathrm{wt} \%)$. The ${ }^{234} \mathrm{U}$ is a decay product of ${ }^{238} \mathrm{U}$, but the ${ }^{235} \mathrm{U}$ is unrelated to the decay products of ${ }^{238} \mathrm{U}$. The nuclides formed from the decay of a radioactive element are called the daughters of the element. A long series of daughters occur in the decay series of ${ }^{238} \mathrm{U}$ until the stable lead isotope ${ }^{206} \mathrm{~Pb}$ is formed. A similar but different series occurs for the decay of ${ }^{235} \mathrm{U}$, which ends in the formation of the stable lead isotope ${ }^{207} \mathrm{~Pb}^{{ }^{C} 1}$ If solid uranium is volatilized to a gas phase, its nonuranium daughters are left behind. When the uranium is resolidified, the concentrations of the daughters will begin to build in the uranium in accordance with the decay rate of the uranium and the decay rate of the daughters. A daughter with a short half-life will begin to approach equilibrium with a parent of long half-life after a period equal to five half-lives of the daughter. When the daughters come into equilibrium with the parent, the dpm of each daughter equals that of the parent. ${ }^{\mathrm{C}-2}$

In uranium ore, all the daughters of ${ }^{238} U$ and ${ }^{235} U$ are observed to be in equilibrium. When $\mathrm{UF}_{6}$ is formed after the ore is processed, the ${ }^{238} \mathrm{U},{ }^{235} \mathrm{U}$, and ${ }^{234} \mathrm{U}$ are constituents of the $\mathrm{UF}_{6}$, but the other nuclides are left behind. Freshly volatilized uranium will have an activity of $1,500 \mathrm{dpm} / \mathrm{mg}$ (48.91\% due to ${ }^{238} \mathrm{U}, 48.91 \%$ due to ${ }^{234} \mathrm{U}$, and $2.18 \%$ due to ${ }^{235} \mathrm{U}$ ). ${ }^{\mathrm{C}-2}$ As long as the uranium is in a gaseous form, the nonvolatile decay daughters will precipitate out of the gas as they are generated. Once the uranium is solidified, the activity will increase as the amounts of decay daughters build in the deposit. Therefore, the total activity emitted from a uranium sample is usually considerably greater than that of pure uranium.

The ${ }^{234}$ Th daughter (half-life $24.1 \mathrm{~d}$ ) of ${ }^{238} \mathrm{U}$ is known to reach $-97 \%$ of the equilibrium activity in $\sim 120 \mathrm{~d}$. The ${ }^{234} \mathrm{~Pa}$ daughter (half-life $1.17 \mathrm{~min}$ ) will approach equilibrium at the same time as the ${ }^{234} \mathrm{Th}$ because of the shorter half-life of the ${ }^{234} \mathrm{~Pa}$, but none of the other nonuranium daughters will approach equilibrium for more than $5 \times 10^{5}$ years. This means that the total activity of a low-assay uranium cascade deposit will be approximately the sum of the emissions from the ${ }^{238} \mathrm{U},{ }^{234} \mathrm{U},{ }^{234} \mathrm{Th}$, and ${ }^{234} \mathrm{~Pa}$, or $-2,950 \mathrm{dpm} /\left(\mathrm{mg}\right.$ of $\left.{ }^{238} \mathrm{U}\right),{ }^{\mathrm{C}-2}$ which is $\sim 4 \times$ the activity of ${ }^{238} U$ alone (neglecting the ${ }^{235} U$ ). Also, since ${ }^{238} U$ and ${ }^{234} U$ are primarily alpha emitters and the ${ }^{234} \mathrm{Th}$ and ${ }^{234} \mathrm{~Pa}$ are beta emitters, one-half of the emissions will be alpha emissions and one-half will be beta emissions. The emissions of the other daughters are small in comparison. If the uranium is then removed by gas-phase treatment, the beta-emitting daughters are left behind but will soon decay to very small amounts of ${ }^{234} U$ (half-life $2.48 \times 10^{5}$ years), which will give relatively very few emissions due to its relatively long half-life. The newly generated ${ }^{234} \mathrm{U}$ could also be removed by gas-phase treatments. The chief difficulty posed by low-assay uranium as relates to gas-phase decontamination concerns the ${ }^{230}$ Th daughter (half-life $7.5 \times 10^{4}$ years) of the ${ }^{234} \mathrm{U}$, which could accumulate significantly in cascade areas that held a large inventory of uranium for a long time, whether that uranium was in the form of $\mathrm{UF}_{6}$ gas or solid uranium deposits.

Uranium-235 in high-enrichment areas is more of a problem than an equivalent amount of ${ }^{238} \mathrm{U}$ from the standpoint of gas-phase decontamination because ${ }^{235} \mathrm{U}$ decays at a rate $\sim 6.3 \times$ that of ${ }^{238} \mathrm{U}$ and generates the isotope ${ }^{231} \mathrm{~Pa}$ (half-life $3.48 \times 10^{4}$ years) via ${ }^{231} \mathrm{Th}$ (half-life $25.6 \mathrm{~h}$ ). Therefore, virtually all ${ }^{231} \mathrm{~Pa}$ generated from the ${ }^{235} \mathrm{U}$ since the start-up of the cascade will still be present, and the amount is slowly increasing. Also, the immediate daughter of ${ }^{231} \mathrm{~Pa}$ is ${ }^{227} \mathrm{Ac}$, with a fairly short half-life of 22 years, and all daughters below 


\section{C-3}

${ }^{2 m}$ Ac have very short half-lives. ${ }^{C_{1}}$ These daughters will add significantly to the overall activity. Once ${ }^{235} \mathrm{U}$ is removed by gas-phase treatments, the radioactive emissions of ${ }^{231} \mathrm{~Pa}$ and its daughters will remain.

The high-enrichment areas of the cascade have accumulated the ${ }^{230} \mathrm{Th}$ daughter of ${ }^{234} \mathrm{U}$ much more so than the low-enriched areas because the ${ }^{234} \mathrm{U}$ concentrated with the ${ }^{255} \mathrm{U}$, due to the enrichment process. The presence of the nonvolatile daughters may impede successful decontamination in areas of the cascades that contained unusually heavy uranium inventories. Since uranium from nuclear reactor tails was fed into the Oak Ridge Gascous Diffusion Plant, significant amounts of technetium $\left({ }^{99} \mathrm{Tc}\right)$ and trace amounts of plutonium $\left({ }^{239} \mathrm{Pu}\right)$ and neptunium $\left({ }^{27} \mathrm{~Np}\right.$ ) may be found in some locations of the cascades. The ${ }^{99} \mathrm{Tc}$ is known to be mobile to some extent, but the effectiveness of gas-phase decontamination on the nuclide is not known. Radiological characterization of the cascades is necessary to determine the extent to which the ${ }^{200} \mathrm{Th},{ }^{231} \mathrm{~Pa},{ }^{99} \mathrm{Tc}$, and other nuclides may impede decontamination. 


\section{C-4}

\section{Appendix C}

\section{REFERENCES}

C-1. A. Brodsky, ed., "Mathematical Equations Used in Radioactive Decay Problems," in CRC Handbook of Radiation Measurement and Protection, Section A, Vol. II: Biological and Mathematical Information, CRC Press, Inc., 1982.

C-2. E. K. Hyde, I. Perlman, and G. T. Seaburg, The Nuclear Properties of the Heavy Elements, Vol. II, Prentice-Hall, Inc., New Jersey, 1964. 


\section{Appendix D}

COST COMPARISON AND ESTIMATES FOR DECONTAMINATION USING THE LTLT PROCESS 


\section{Appendix D \\ COST COMPARISON AND ESTIMATES FOR DECONTAMINATION USING THE LTLT PROCESS}

In 1991, Ebasco Services completed a study'D.1 entitled "Environmental Restoration of the Gaseous Diffusion Plants," which developed preliminary cost estimates for decontamination and decommissioning of the gaseous diffusion facilities at the K-25 Site, PGDP, and PORTS. The Ebasco study assumed a "mobile" gas-phase decontamination process would be required to remove deposits in situ at locations where criticality dangers exist. These locations would be identified by gamma spectroscopy surveys. They also assumed that high-temperature gas-phase decontamination furnace stands would be built in two separate decontamination facilities to provide a pretreatment to remove $>90 \%$ of the uranium deposits before further decontamination using a high-pressure water process. A highassay decontamination facility (HADF) was proposed to process equipment from high-assay areas, and a low-assay decontamination facility (LADF) was proposed to process equipment that does not pose criticality and safeguard concerns.

When the LTLT method as proposed in this report is compared with the method proposed in the Ebasco study, large potential cost savings are obvious with the LTLT process. Table D.1 provides a breakdown of some of the more direct cost reductions that are based on information extracted from the Ebasco study. ${ }^{\mathrm{D}-1}$

Table D.1. Estimates of direct construction and operating costs of the high-temperature furnace stands

\begin{tabular}{lcc}
\hline Labor/materials & $\begin{array}{c}\text { HADF } \\
\text { (costs in millions } \\
\text { of 925) }\end{array}$ & $\begin{array}{c}\text { LADF } \\
\text { (costs in millions } \\
\text { of 925) }\end{array}$ \\
\hline Direct construction costs & 117.8 & 230.4 \\
Direct operating costs & 6.8 & 6.6 \\
Direct maintenance costs & 8.2 & 12.6 \\
Indirect costs and adders & $\underline{57.1}$ & 107.3 \\
Sum & 189.9 & 356.9 \\
HADF and LADF combined sum & 546.8 & \\
Cost adders associated with & & \\
construction management, M\&D & & \\
contractor, and contingencies & 200.2 & \\
Total & 747 & \\
\hline
\end{tabular}

The costs of $\$ 747 \mathrm{M}$ shown in Table D.1 include only elements associated with construction and operation of the high-temperature furnace stands, which would be eliminated by the LTLT method. Additional cost reductions due to the LTLT method are likely, although a quantitative evaluation is difficult. The overall size of the high-pressure 
water decontamination facility, which was estimated at $\$ 174 \mathrm{M}$ by Ebasco, would likely be reduced considerably. Simplifications in radiation exposure-control procedures and simplification in requirements for personnel protection equipment will likely result from the in situ process that will significantly reduce the $\$ 63 \mathrm{M}$ estimate for gaseous diffusion equipment disassembly costs. The Ebasco estimate assumed an additional \$44M in capital and operating costs would be spent for in situ gas-phase pretreatment to remove deposits that constitute a criticality hazard before the contaminated equipment is moved. The capital costs associated with the LTLT equipment are expected to be very low in comparison with the costs of the furnace stand facilities. Table D.2 contains a cost estimate for design and construction of the full-scale LTLT equipment. Since a large portion of the $\$ 2.9 \mathrm{M}$ total is engineering design costs, additional units of LTLT equipment could be expected to cost considerably less.

The operating costs of the LTLT process are difficult to estimate accurately because the cost of successfully leak-proofing the gaseous diffusion equipment is not well known. The most obvious source of leaks are the compressor seals, and more accurate cost estimates will be possible once methods for sealing the seals are devised. The considerations listed here give a person reason to believe that the operating costs of the LTLT process. will be less than the furnace stand process.

- The furnace stand process requires that the items be removed from the cascade and be transported to the furnace stand. This step is not required for the LTLT method.

- Once at the furnace stand, the item must be installed in the furnace, which will involve sealing the item in the process gas flow loop and leak testing the item. This sealing and leak testing operation may be as expensive as sealing and leak testing for the LTLT application, but a direction comparison is difficult because the LTLT method requires tighter sealing since it is a longer-term process.

- The operator time required for the furnace stand method is likely to be more than that required for the LTLT method because the LTLT method does not require that the operators be present during the chemical reaction time, except to periodically check the pressure and perhaps the gas composition.

- The furnace stand facilities and support equipment will also require decontamination at the conclusion of the project. The LTLT process equipment will be much less expensive to decontaminate than the furnace stand facilities because of the much smaller amount of equipment involved.

Table D.3 contains a rough cost estimate for decontamination of a single 00 converter. This estimate is for a production application rather than a demonstration application; therefore, the technical support costs and certain other costs are shown as much lower than would be expected for an early demonstration run. Since a demonstration on full-size equipment has not yet been done, the cost of $\$ 15 \mathrm{~K}$ cost must be viewed as a very rough approximation. The estimate of $\$ 15 \mathrm{~K}$ for the $28,800-\mathrm{lb}$ converter amounts to $\$ 0.52 / \mathrm{lb}$. If the LTLT method is applied to an entire cell at once, the cost may be much less than this estimate. 
D-4

Table D2 Design and construction cost estimate for LTLT equipment

Labor/materials

Costs

(SK)

Technical Services support to

Engineering

MMES Engineering Titles I \& II

MMES Engineering Title III

Engineering construction support

Cost of roughing pump and chemical traps, instrumentation, cylinder manifolds, gas analyzer and other items

Cost of modifications to trailer for equipment support

S.S. stack and isokinetic sampler

Piping, valves, electrical equipment, and miscellaneous items

Installation and construction costs

Salaried field support

Facility for recovery of $\mathrm{UF}_{6}$

$30 \%$ contingency

666 


\section{D-5}

Table D.3. Rough operating cost estimate for decontamination of an 00 converter

\begin{tabular}{|c|c|c|}
\hline Labor/materials & & $\begin{array}{l}\text { Costs } \\
(\$)\end{array}$ \\
\hline Seal and leak test the converter & & 4,000 \\
\hline $\begin{array}{l}\text { Move and connect equipment to the } \\
\text { converter-two chemical operators } \\
\text { and one supervisor for } 2 \mathrm{~h}\end{array}$ & $3 \times 2 \mathrm{~h} \times \$ 103.45 / \mathrm{h}=$ & 620 \\
\hline $\begin{array}{l}\text { Evacuate, add } \mathrm{F}_{2} \text { gas to dry the } \\
\text { converter, evacuate gases, charge } \\
\text { with chlorine trifluoride and } \\
\text { seal-two chemical operators and } \\
\text { one supervisor for } 6 \mathrm{~h}\end{array}$ & $3 \times 11$ h $\times \$ 103.45 / h=$ & 3,414 \\
\hline $\begin{array}{l}\text { Move and connect to the converter } \\
\text { (months later-meanwhile, charge } \\
\text { other items) }\end{array}$ & $3 \times 2 \mathrm{~h} \times \$ 103.45 / \mathrm{h}=$ & 620 \\
\hline $\begin{array}{l}\text { Evacuate gases and capture UF, in } \\
\text { the sodium fluoride trap }\end{array}$ & $3 \times 6 \mathrm{~h} \times \$ 103.45 / \mathrm{h}=$ & 1,860 \\
\hline $\begin{array}{l}\text { Technical support (averaged per } \\
\text { converter) }\end{array}$ & & 200 \\
\hline $\begin{array}{l}\text { Material cost, sampling, and waste } \\
\text { disposal (averaged per converter) }\end{array}$ & & 1,000 \\
\hline \multirow{4}{*}{$\begin{array}{l}\text { Health Physios, Industrial Hygiene, } \\
\text { utilities, and clothing (averaged } \\
\text { per converter) }\end{array}$} & & 800 \\
\hline & Total & 12,514 \\
\hline & Contingency @ 20\% & 2,503 \\
\hline & $\begin{array}{l}\text { Total per converter } \\
\text { (roughly estimated) }\end{array}$ & 15,017 \\
\hline
\end{tabular}




\section{D-6}

\section{Appendix D}

\section{REFERENCES}

D-1. Ebasco Services, Environmental Restoration of the Gaseous Diffusion Plants, Vols. 1 and 2, prepared under contract with U.S. DOE/UE, Oak Ridge, Tenn., October 1991.

D-2. B. E. Prince, Martin Marietta Energy Systems, Inc., the Oak Ridge K-25 Site, personal communication to E. B. Munday, Martin Marietta Energy Systems, Inc., the Oak Ridge K-25 Site, October 1992. 


\section{INTERNAL DISTRIBUTION}

Oak Ridge K-25 Site

W. D. Altman

H. L. Bailey, Jr.

E. J. Barber

C. E. Benson

W. D. Bostick

N. P. Brady

R. D. Bundy

T. W. Burwinkle

F. P. Delozier

R. S. Eby

D. E. Fain

R. L. Fellows

J. M. Googin

L. E. Hall

H. H. Haselton

R. L. Higgins

J. M. Kennerly

R. K. Kibbe

L. D. Ladd

J. R. Merriman

E. B. Munday

D. W. Neiswander

J. H. Pashley

F. S. Patton

G. A. Person

B. E. Prince

A. S. Quist (3)

R. L. Ritter

W. D. Simmons

D. B. Smith

L D. Trowbridge

Y. W. Walton - K-25 Publications

Applied Technology Library

K-25 Site Plant Records

Portsmouth Gascous Diffusion Plant

J. G. Crawford

R. T. Shelton

Portsmouth Library

\section{Department of Energy - Headquarters}

T. D. Anderson

C. W. Frank

K. E. Hain

J. M. Hyde

J. L. Kelly

J. M. Lankford

W. E. Murphy

L. H. Taylor

H. Thron

R. P. Whitfield

Department of Energy - Oak Ridge

M. R. Jugan

J. O. Moore

E. J. Powell

F. P. Riddle

R. C. Sleeman
Paducah Gaseous Diffusion Plant

PGDP Library

\footnotetext{
"Two copies to the Office of Scientific and Technical Information.
} 